\title{
Confederate Borderland, Indian Homeland: Slavery, Sovereignty, and Suffering in Indian Territory
}

\author{
Zachery Christian Cowsert \\ West Virginia University
}

Follow this and additional works at: https://researchrepository.wvu.edu/etd

\section{Recommended Citation}

Cowsert, Zachery Christian, "Confederate Borderland, Indian Homeland: Slavery, Sovereignty, and Suffering in Indian Territory" (2014). Graduate Theses, Dissertations, and Problem Reports. 108. https://researchrepository.wvu.edu/etd/108

This Thesis is protected by copyright and/or related rights. It has been brought to you by the The Research Repository @ WVU with permission from the rights-holder(s). You are free to use this Thesis in any way that is permitted by the copyright and related rights legislation that applies to your use. For other uses you must obtain permission from the rights-holder(s) directly, unless additional rights are indicated by a Creative Commons license in the record and/ or on the work itself. This Thesis has been accepted for inclusion in WVU Graduate Theses, Dissertations, and Problem Reports collection by an authorized administrator of The Research Repository @ WVU. For more information, please contact researchrepository@mail.wvu.edu. 


\title{
Confederate Borderland, Indian Homeland: \\ Slavery, Sovereignty, and Suffering in Indian Territory
}

\section{Zachery Christian Cowsert}

\author{
Thesis submitted \\ to the Eberly College of Arts and Sciences \\ at West Virginia University \\ in partial fulfillment of the requirements for the degree of \\ Master of Arts in \\ History
}

\author{
Brian Luskey, Ph.D., Chair \\ Aaron Sheehan-Dean, Ph.D. \\ Tyler Boulware, Ph.D. \\ Department of History
}
Morgantown, West Virginia
2014

Keywords: Indian Territory, Civil War Copyright 2014 Zachery Christian Cowsert 


\section{ABSTRACT \\ Confederate Borderland, Indian Homeland: Slavery, Sovereignty, and Suffering in Indian Territory}

\section{Zachery Christian Cowsert}

This thesis explores the American Civil War in Indian Territory, focusing on how clashing visions of sovereignty within the Five Tribes - Cherokee, Chickasaw, Choctaw, Creek, and Seminole - led to the one the most violent and relatively unknown chapters of the Civil War. Particular attention is paid to the first two years of the war, highlighting why the Five Tribes allied with Confederacy, and why those alliances failed over time. Chapter One examines Indian Territory as a borderland, unveiling how various actors within that borderland, including missionaries, Indian agents, white neighbors in Arkansas and Texas, and Indians themselves shaped Native American decision-making and convinced acculturated tribal elites to forge alliances with the Confederacy. These alliances, however, did not represent the sentiments of many traditionalist Indians, and anti-Confederate Creeks, Seminoles, and African-Americans gathered under the leadership of dissident Creek chief Opothleyahola. Cultural divisions within the Five Tribes, and differing visions of sovereignty in the future, threatened to undermine Indian-Confederate alliances. Chapter Two investigates the Confederacy's 1861 winter campaign designed to quell Opothleyahola's resistance to Confederate authority. This campaign targeted enemy soldiers and civilians alike, and following a series of three engagements Opothleyahola's forces were decisively defeated in December. During this campaign, however, schisms with the Confederate Cherokees became apparent. In the weeks that followed, Confederate forces pursued the men, women, and children of Opothelyahola's party as they fled north across the frozen landscape for the relative safety of Kansas. The military campaign waged in 1861, and the untold suffering heaped upon thousands of civilians that winter, exposes how a hard, violent war rapidly emerged within the Confederate borderland, complicating historians' depiction of a war that instead grew hard over time.

Chapter Three documents the return of Federal forces to the borderland via the First Indian Expedition of 1862. Although the expedition was a military failure, the sudden presence of Union forces in the region permanently split the Cherokee tribe into warring factions. The Cherokee, Creek, and Seminole tribes spent the next three years fighting their own intra-tribal civil wars. Moreover, the appearance and retreat of Federal forces from Indian Territory created a geopolitical vacuum, which would be filled by guerrilla violence and banditry. The failure of either Confederate or Union forces to permanently secure Indian Territory left Indian homelands ripe for violence and lawlessness. The thesis concludes by evaluating the cost of the conflict. One-third of the Cherokee Nation perished during the war; nearly one-quarter of the Creek population died in the conflict. By war's end, two-thirds of Indian Territory's 1860 population had become refugees. Urged to war by outsiders and riven with their own intra-tribal strife, Native Americans of the Five Tribes suffered immensely during the Civil War, victims of one of the most violent, lethal, and unknown chapters in American history. 


\section{Acknowledgements}

The master's thesis, far from being the sole product of the author, in fact represents the ideas, feedback, and encouragement of all those who helped the author along the way. This thesis is no different. I want to sincerely thank my advisor, Dr. Aaron-Sheehan Dean, who despite distance remained steadfast in helping this project grow from an idea to a reality. Dr. Brian Luskey offered critical feedback as well, particularly in regards to the first chapter which evolved in his graduate seminar course. Dr. Tyler Boulware provided thoughts that helped me better understand this project from a Native American perspective. Staff from a variety of institutions were wonderfully helpful in tracking down sources; my thanks to the staff of the Oklahoma Historical Society, the Western History Collection at the University of Oklahoma, the Presbyterian Historical Society, and West Virginia University's Wise Library. Fellow graduate students at West Virginia University gave their thoughts and encouragement as well and were a great source of relief and entertainment when needed. Last, I'd like to offer a special thanks to my parents Rick and Erin Cowsert and my sister Alex Cowsert, who offered me an abundance of support and put up with my historical ramblings. I owe them much. 


\section{Table of Contents}

$\begin{array}{ll}\text { Introduction } & 1\end{array}$

$\begin{array}{ll}\text { Chapter One: Secession and the South } & 7\end{array}$

$\begin{array}{ll}\text { Chapter Two: Fight and Flight } & 38\end{array}$

Chapter Three: The Federal Indian Expedition 65

$\begin{array}{lr}\text { Conclusion } & \mathbf{8 0}\end{array}$

$\begin{array}{lr}\text { Bibliography } & 84\end{array}$ 


\section{Introduction}

Thousands of Cherokees gathered in the Cherokee capital of Tahlequah in the heart of Indian Territory to witness the day's momentous proceedings in the autumn of 1861 . On hand were Confederate General Albert Pike and Superintendent of Indian Affairs Elias Rector; both men satisfied at the culmination of months of diplomatic wrangling, saber-rattling, and pleading. These newly-minted Southern leaders had finally convinced the Cherokee Nation to align with the nascent Confederacy, and today, on September 25, the treaty of alliance would be signed. The last of the Five Civilized Tribes in Indian Territory-Cherokee, Chickasaw, Choctaw, Creek, and Seminole - had come into the Confederate fold. ${ }^{1}$

As two Cherokee leaders signed the treaty, they looked upon one another. On one side stood John Ross, Principal Chief of the Cherokee Nation and champion of the everyday Cherokee people. Perhaps for him, at least internally, this day was not one for celebration. Ross had fought for months to keep the Cherokees out of the looming civil war, to let the tranquility and peace of neutrality cover the Nation. It was not to be. Ross was here to reluctantly send his nation to war. Across from John Ross stood Stand Watie, who had sought an alliance with the South from the very beginning. For Stand Watie, Cherokee interests, especially those of the elite, acculturated class to which he belonged, were clearly aligned with those of the Southern states. This September gathering was Watie's triumphant moment. The Cherokee Nation had cast its lot with the South and, for the time being at least, its two great leaders stood side by side

\footnotetext{
${ }^{1}$ Since civilization is a relative term, the Five "Civilized" Tribes will be referred to as the Five Tribes for the remainder of this paper. Indian Territory encompasses modern-day Oklahoma, and each of the Five Tribes would ultimately have bordered nations located in the eastern and central portions of the Territory. To stave off repetition, the terms Indian, Native American, and native will be used interchangeably.
} 
under the Stars and Bars. Southern neighbors and newspapers, who had watched intently to see which way the Indians would go, crowed about the diplomatic victory for weeks to come. ${ }^{2}$

These two men—John Ross and Stand Watie_-embodied the two differing visions of Indian sovereignty and future that occupied Indian Territory in the crisis months of 1861 . These dueling visions of the future — one of Indians as sovereign members of wider Confederate society, the other of Indians preserving their traditional way of life under old Federal treatieswere mutually exclusive, and their exclusivity would lead to profound violence. This story, then, is how irreconcilable visions of the future generated one of the most-destructive chapters in American history.

It is not surprising to find that whites were so heavily invested in the Five Tribes' decision-making process in the crisis moment of 1861. On the verge of the Civil War, Indian Territory transformed into a borderlands between two continental powers, where vibrant and sometimes violent exchanges of political, religious, cultural, and ideological ideas between Native-Americans and their white counterparts took place. As war loomed on the horizon, Indians were forced to choose sides, and their choices proved of great interest to, and were heavily influenced by, white missionaries, Indian agents, and neighbors. The external pressure exerted by whites accentuated pre-existing cultural cleavages among the Five Tribes. Even prior to their removal in the 1830 's, each of the Five Tribes suffered schisms between those who wanted to adopt white, Southern lifestyles and those who sought to preserve traditional, native ways of life. By 1861, acculturated Indian elites controlled native governments, and many of these elites recognized their precarious geopolitical circumstances and proved receptive to white Confederates overtures of alliance. Seeing their interests as intertwined with those of the South,

\footnotetext{
${ }^{2}$ Dallas Herald, vol. 9, no. 49, September 11, 1861; The [Clarksville] Standard, October 26, 1861.
} 
Indian elites forged treaties of alliance with the nascent Confederacy, with all Five Tribes in the Confederate fold by the autumn of 1861 .

Yet elites' visions of themselves as Southerners clashed with the visions of traditional Indians, who spurned the changes acculturation brought and sought to protect Indian distinctiveness and sovereignty. Almost before the ink on the various Confederate-Indian treaties had dried, traditional Indians under the leadership of Creek chief Opothleyahola had gathered to resist Confederate authority. As traditional Indians flocked to Opothleyahola's banner, Confederate military authorities sought to silence this dangerous voice of dissent. Launching an 1861 winter offensive, Confederates inaugurated a military campaign not only meant to defeat enemy warriors, but a campaign also designed to drive Unionists civilians out of the country. The result was a series of three hard-fought battles that culminated in Opothleyahola's defeat. Worse still, it sent thousands of Opothleyahola's civilian followersmen, women, and children — fleeing northwards across the frozen landscape as refugees. Their plight, largely forgotten to history, testifies to the perpetration of a type of "hard war" that historians contend would not arise until late in the war years. Yet in the Confederate borderlands, clashing Native-American visions of the future and distance from centers of power allowed brutal violence and civilian suffering to appear in the war's first months. Moreover, the 1861 campaign against Opothleyahola exposed the fragility of the Confederate-Indian alliances, foreshadowing great conflict to come.

In 1862, the United States government, a year and a half absent from the political and military rumblings in Indian Territory, finally returned to the borderlands in the first of two expeditions that ultimately imposed Union dominance over the region. Although the 1862 expedition fizzled out quickly, the reappearance of U.S. military forces permanently tore asunder 
the schisms between traditional and acculturated Indians that had been simmering. The Cherokee, Creek, and Seminole tribes split into warring faction, and intra-tribal civil war devastated these tribes over the war's remaining years. While the 1862 expedition pushed Confederate forces out of much of the Territory, the expedition's ultimate retreat created a vacuum of power from which a whirlwind of guerrilla violence, banditry, and suffering was spawned. This endless, localized violence scarred the landscape and its people, impacting thousands of lives and marking the Confederate borderlands as one of the most war-torn theaters of the American Civil War and one of the most brutal Indian Wars in American history.

This story of sovereignty, violence, and suffering, is told in three chapters. Chapter One investigates Native-American decision making during the secession crisis of 1861, detailing how various members of the borderlands, including Native-Americans themselves, helped forge treaties of alliance between the Five Tribes and the Confederacy. Relatively few scholars have examined the wartime decision-making and experiences of the Five Tribes; those that have often focus on the experiences of a single tribe. A modern, collective exploration of the Five Tribes' position in the conflict offers greater understanding of the region, and helps illuminate the interconnectedness of Indian Territory as a borderland. In recent years, historians have grown wary of the elasticity of the term "borderland," cautioning that overuse may render the term meaningless. Acknowledging the legitimacy of this concern, it is important to define precisely how Indian Territory became a borderland. Even prior to war, Indian Territory marked itself as a place of great cultural, religious and ideological exchange, where white neighbors, Indian agents, and missionaries all sought to reshape Native-American ways of life. With the secession of the Confederate States in 1861, however, Indian Territory transformed from a cultural and ideological borderland into a very literal political borderland, a place bounded on all sides by 
either the United or Confederate States. And although secession may have added a political

component to the borderlands, those prewar agents of acculturation worked hard to push the Five

Tribes into the Confederate fold, a successful venture that marked the borderland as a

Confederate one. ${ }^{3}$

Chapter Two illuminates the forgotten 1861 winter campaign against Opothleyahola, whose followers turned into Unionists as the made their way north across the frozen hills of northern Indian Territory. This campaign of aggression and terror was waged by both white and Indian Confederates, and attention is paid to how war made strange bedfellows of white Southerners and their Indian comrades-in-arms. Most importantly, however, this chapter documents a Confederate campaign that was vicious both on the battlefield and off. Civilians found themselves targets of Confederate aggression, both their morale and physical well-being under attack. Historians of the Civil War cast their eyes across the Mississippi far too little and pay attention to a military backwater like Indian Territory even less. Yet in this backwater, in

\footnotetext{
${ }^{3}$ There are several works that offer some insight into the experience of Indians during the Civil War. Lawrence Hauptman's Between Two Fires: American Indians in the Civil War (1995) offers an episodic overview of all Native American involvement in the war, not just the Five Tribes in Indian Territory. Indeed, Hauptman largely focuses on the Delaware tribe's experience in the Territory during the war. The first work to survey the conflict in Indian Territory was a trilogy of books by Annie Heloise Abel, notably The American Indian as Slaveholder and Secessionist (1915) and The American Indian in the Civil War, 1862-1865 (1919). Although nearly a century old, Abel's work remains the only piece of scholarship to deeply examine the Five Tribes' collective experience during the Civil War. Abel contends that the tribes allied with the Confederacy due to economic and social ties between the Five Tribes and the South. Since Abel, several authors have explored particular tribal experiences during the war. Benton and Christine White's Now the Wolf Has Come: The Creek Nation in the Civil War tries to uncover the Creek experience in during the early stages of the war. Although useful for understanding Creek mindset, the Whites' book often adopts first-person narratives that blur the lines between scholarship and storytelling. The Cherokee Nation in the Civil War (2007) by Clarissa Confer offers an excellent overview of Cherokee involvement in the war, paying particular attention to the suffering of civilians. A number of books examine Indian military units on both sides, most notably Craig Gaines' The Confederate Cherokee: John Drew's Regiment of Mounted Rifles which documents the desertion and defection of many Southern Indians to the Union cause. The only modern book to examine the Union's war efforts in the Territory, Mark Lause's Race and Radicalism in the Union Army (2009) explains how intellectual radicals and abolitionists in Kansas helped shape Union drives to reconquer the Territory and utilize Indian soldiers. Most of the secondary Native-American literature upon which I have drawn are general histories of the various tribes, which often contain a single chapter on the Civil War years. For more on the various Five Tribes generally, see Grace Steele Woodward's The Cherokees, Civilization of the American Indian Series (Norman: University of Oklahoma Press, 1963), Angie Debo, The Rise and Fall of the Choctaw Republic, Civilization of the American Indian Series (Norman: University of Oklahoma Press, 1934), Angie Debo, The Road to Disappearance: A History of the Creek Indians (Norman: University of Oklahoma Press, 1941), and Arrell M. Gibson's The Chickasaws (Norman: University of Oklahoma Press, 1971).
} 
the very first year of the war, a violent campaign was waged to drive anti-Confederate Indians out of the country, including warriors, women, and children. This campaign complicates the declensionist narrative of war's violence that historians portray, where 1864 stands as a turning point for military commanders willing to ratchet up the war's intensity and target civilian morale. $^{4}$

Chapter Three follows the Union army as it returns in 1862 to the borderlands in abandoned in 1861. Although the campaign was a short-lived military failure, it permanently divided three of the Five Tribes and ensured that guerrilla violence and banditry would haunt the land for years. This chapter places Indian Territory alongside better-examined theaters such as wartime Missouri, Arkansas, and Tennessee_- places where constant, localized warfare ruined the landscape, with civilians once again the victims of violence. The conclusion tallies up the final cost of this virulent struggle for sovereignty and control, acknowledging the death and destruction that shattered the Confederate borderland. ${ }^{5}$

\footnotetext{
${ }^{5}$ In writing this work, I have relied upon a variety of primary sources from a host of (often surprising) archives and locales. Missionary reports, government documents, soldiers' letters and service records, Indian correspondence, 1930's Federal Writers' Project oral interviews, the Official Records of the War, Census data, genealogical research, and more were all critical in uncovering and understanding various aspects of the Civil War saga in Indian Territory. I have also had the pleasure of traversing some — though not all —of the ground and geography I discuss, an intangible but immensely useful enterprise. Still, I should point out that certain silences proved difficult for me to overcome. Overwhelmingly, my sources were Confederate or pro-Southern in their outlook. To a certain extent, this was beneficial - more often than not, Southerners or pro-Southern Indians are the most active protagonists in this story. Unfortunately, however, far fewer sources illuminate the experiences and motivations of Unionist Indians. To a certain extent, I have had to read against the grain, utilizing the contours of what Confederates did and did not say to understand the shape of Union actions. I have also at times had to rely upon oral interviews held decades after the events they discussed. While I have tried to exercise the utmost care in drawing upon these sources, honesty begs me to note their problematic nature.
} 


\section{Chapter One: Secession and the South}

Indian Territory encompassed a web of cultural, religious, economic, ideological, and political exchanges that marked the area as a southern, and in turn Confederate, borderland. Indians and their leaders interacted with one another, missionaries, Indian agents, and their anxious white neighbors in Arkansas and Texas, and these exchanges shaped Native Americans' diplomatic decision-making in the secession crisis. As the United States broke in two in 1861, the Five Tribes found themselves caught in the conflict's whirlwind. Their own internal debates over what course to pursue - neutrality, continued allegiance to the United States, or a new beginning with a new Confederacy_-were profoundly influenced by these outside actors. Externally-induced debates over slavery, neighbors' pleading entreaties and threats of violence, cajoling Indian agents, and internal Indian cultural and political cleavages shaped Indiandecision making. These diplomatic, political, and cultural exchanges between Indians and various outsiders helped shape the Five Tribes decision making in 1861. Ultimately, borderland interactions, hard geopolitical realities, and a belief that Indians' best interests and brightest future lay with a Confederacy pushed acculturated elites, and the native governments they controlled, into alliances with the emerging Confederate States.

As trusted members of both Indian and white societies, missionaries wielded significant influence among the Five Tribes, focusing on civilizing, proselytizing, and educational goals. Yet during the 1850 's, a small minority of abolitionist missionaries inserted the slavery question into Indian affairs, reigniting older cultural and political feuds. Christian missionaries, charged with civilizing the Five Tribes, instead battled over the what "civilization" meant themselves, bringing the national debate over slavery into Indian Territory. The result was an increasingly 
fearful political climate, where Indian elites and white neighbors saw abolitionist schemes in every corner. When the secession crisis emerged in the summer of 1861, the wider cultural and political schisms that abolitionism helped ignite shaped Indian elites' decision-making. Invested in a slaveholding economy and fearful of abolition's grasp, wealthy Indians sought solidarityand alliance — with the South.

Despite their small number, missionaries enjoyed an important, influential place in Indian society. Although missionary work had begun in the colonial era, it was the Second Great Awakening that brought increased missionary efforts to Native Americans. Missionaries had played a prominent role in opposing the fraudulent process of Indian removal the United States had implemented in the 1820's and 1830's. They often worked among a single tribe for much of their lives, and upon removal, many missionaries followed their flocks to new homes in the West. Thus, missionaries built rapport and trust with native leaders and communities throughout the early $19^{\text {th }}$ century. ${ }^{6}$

In both the old lands and new, missionaries worked to convert Native Americans to both Christianity and white Americans' way of life. Missionaries delivered sermons in native languages, translated hymns and Bible chapters, and established churches, missions, and Christian organizations. Cyrus Byington's career is indicative of the kind of work missionaries performed. Riding a circuit of nearly 100 miles, Byington preached at five different locations and spent his spare time writing Choctaw-English language books. Stephen Foreman, missionary among the Cherokees, helped develop the Cherokee Bible Society. Announcements

\footnotetext{
${ }^{6}$ Clarissa Confer, The Cherokee Nation in the Civil War (Norman: University of Oklahoma Press, 2007): 27-2-8. It was a missionary, Reverend Samuel Worcester, who challenged the legality of fraudulent treaty forcing the Cherokees to move west in the 182 Supreme Court case Worcester v. Georgia. Despite the Supreme Court siding with Worcester and the Cherokee, the removal continued anyways. Worcester continued his missionary work in Indian Territory.
} 
for temperance groups, Bible societies, and fraternal organizations dot antebellum issues of Territorial newspapers such as the Cherokee Advocate and Choctaw Intelligencer. ${ }^{7}$

Missionaries also promoted Indian education, helping create public school systems throughout the Territory and opening schools of their own. By the 1850's, for example, the Cherokee, Chickasaw, Choctaw, and Creek Nations all had brick and mortar academies for promising Indian students. Prominent Indian families also had the chance to send their sons to schools in the United States, usually in the South. Young George Washington Grayson, a Creek and future Confederate, studied in a school house "built of stakes driven in the ground and weather boarded and roofed with clapboards" in 1859. Months later, Grayson found himself on the campus of Arkansas College in Fayetteville. He wrote of his experience, "I became more civilized and more careful of my apparel and personal appearance, and thereafter had my clothing cut and sewed by the city tailor, and in the prevailing style." Education inculcated Indians, especially elites, to white ways of life, and for those who studied abroad in the United States, it often steeped students in Southern lifestyles. ${ }^{8}$

To be sure, there were limits to missionaries' progress. The head of a Creek manual school in 1859 reported exasperatedly, "The people, generally, do not appreciate the importance of education sufficiently to require their children to attend school....[A]ttendance at the day schools is very irregular." Christianity only took shallow root amongst the Five Tribes. While certainly many Indians were exposed to Christianity, relatively few adopted or practiced it with any regularity. By 1860, for example, only 12 percent of Cherokees belonged to any Protestant

\footnotetext{
${ }^{7}$ Louis Coleman, "Cyrus Byington: Missionary to the Choctaws," Chronicles of Oklahoma 62, no. 4 (1984): 370-371; for specific examples of Christian advertisements, see Choctaw Intelligencer, October 18,1851 and Cherokee Advocate, September 26, 1844.

${ }^{8}$ Arrell M. Gibson, The Chickasaws (Norman: University of Oklahoma Press, 1971): 202-204; George Washington Grayson, A Creek Warrior for the Confederacy (Norman: University of Oklahoma Press, 1988): 38, 53.
} 
denomination. Traditional Indian beliefs continued to abound. Whatever the limitations, however, the dozens of missionaries among the Five Tribes had proven their influence in shaping Indian education, salvation, and culture. ${ }^{9}$

By the 1850 's, however, “civilization” became an increasingly disputed term as certain missionaries began to preach abolitionist ideals. Abolitionism, as elsewhere in the South, was unwelcome in a slaveholding society, and chattel slavery was wholly adopted and practiced by all Five Tribes in the Territory. Slaveholding, especially among the wealthier, acculturated elites, was not uncommon. Robert M. Jones, a Choctaw and one of the wealthiest figures in Indian Territory, operated six plantations that produced hundreds of bales of cotton annually. Such an operation required tremendous amounts of labor, and 227 slaves worked Jones' fields. Of course, Jones was an exception-most Indians who owned slaves held five or less. Still, slavery permeated Indian Territory. The total population of the Territory in 1860 was 58,594: $82 \%$ Indian, $14 \%$ slaves, and $4 \%$ white. Approximately 8,376 blacks were held in bondage by Indians, mostly the acculturated, wealthy elite. ${ }^{10}$

These statistics indicate that slavery within Indian Territory more closely resembled slavery in the border states than that of the Upper or Deep South. Slaves comprised 12.7 percent of the border states' population; similarly, slaves constituted 14.2 percent of Indian Territory’s

\footnotetext{
${ }^{9}$ Report of the Commissioner of Indian Affairs for the Year 1859 (Washington: George W. Bowman, 1860): 182; William G. McLoughlin, The Cherokees and Christianity, 1794-1870 (Athens: University of Georgia Press, 1994): 19.

${ }^{10}$ Michael L. Bruce, “'Our Best Men are Fast Leaving Us:' The Life and Times of Robert M. Jones,” Chronicles of Oklahoma 66, no. 3 (1988): 294-296; Michael F. Doran, "Negro Slaves of the Five Civilized Tribes," Annals of the Association of American Geographers 68, no. 3 (Sept., 1978): 348; Michael F. Doran, "Population Statistics of Nineteenth-Century Indian Territory," Chronicles of Oklahoma 53, no. 4 (1975): 501.
} 
population in 1860. Comparatively, slaves made up 30 percent and 58.5 percent of the populations of the Upper and Lower South, respectively. ${ }^{11}$

Years of interaction with whites had ensured that Indian-black relations roughly mirrored those of white-black relations. All free blacks were expelled from Choctaw lands in 1840. By 1846, manumission of slaves by Choctaw owners could only come with the permission of the Choctaw General Council. Similarly, during the 1840's the Cherokee National Council passed a series of black codes that resembled those of other Southern states. Slave patrols were created. Blacks were prohibited from carrying weapons or learning to read or write. Masters were held accountable for their slaves' actions. Prior to the Civil War, racial views hardened among the Five Tribes. $^{12}$

Yet while Indians adopted Southern racial views, missionaries from the North increasingly advocated abolitionism. At the center of this movement stood Evan Jones and his son John, Baptist preachers from the North. With the "sincere desire and earnest prayer that [slavery] may be speedily brought to an end," the Joneses worked to combat the influence of slavery in Indian Territory, particularly among the Cherokee. ${ }^{13}$

As mentioned above, the Cherokee were split into two economic and social factions: the wealthy, slave-owning, often mixed-blood elite who dominated Cherokee politics and the less affluent, small-farming, often full-blood traditionalists who comprised a far greater portion of the Nation but were left largely without economic and political power. These cleavages created natural fault lines along which the slavery debate grew. In 1855, Cherokee Chief John Ross

\footnotetext{
${ }^{11}$ William W. Freehling, The South vs. The South: How Anti-Confederate Southerners Shaped the Civil War (New York: Oxford University Press, 2001): 18-19. Freehling defines the border states as Missouri, Kentucky, Maryland, and Delaware.

${ }^{12}$ Barbara Krauthamer, Black Slaves, Indian Masters: Slavery, Emancipation, and Citizenship in the Native American South (Chapel Hill: University of North Carolina Press, 2013): 71; R. Halliburton, Jr., Red Over Black: Black Slavery among the Cherokee Indians (Westport, CT: Greenwood Press, 1977): 80-84.

${ }^{13}$ Patrick Minges, Slavery in the Cherokee Nation: The Keetowah Society and the Defining of a People, 1855-1867 (New York: Routledge, 2003): 66.
} 
informed the Baptist Joneses of the existence of pro-slavery secret society among the mixedblood Cherokees, an organization with apparent ties to southern states. This pro-slavery "secret society" would eventually evolve into an Indian chapter of the infamous Knights of the Golden Circle, dominated largely by wealthy elites. Working with native preachers, the Joneses formed their own counter-organization, the Keetowah Society. Comprised of traditional, conservative Indians, the Keetowah practiced a syncretic religion that blended aspects of Christianity, Cherokee tradition, and brotherhood. Although generally anti-slavery, as scholar William McLoughlin has deftly argued, the "immediate purpose of the Keetowah Society was to combat those mixed-bloods who wanted to link the Cherokees' destiny to that of the white southern nationalist movement in the United States." Debates over slavery, fueled by missionaries and deepened by pre-existing social rifts, were pulling the Cherokee Nation in opposite directions. ${ }^{14}$

Although precise numbers are not known, it is unlikely the Keetowah Society ever encompassed more than a sliver of the Cherokee population in antebellum years. Yet despite its small size, the Keetowah Society and abolitionism in general struck fear into the hearts of wealthy Indian slaveholders of all Five Tribes and the tribal governments they dominated. Choctaw George Hawkins was of the "opinion that those stinking abolitionists will yet cause the Choctaws a great deal of trouble...They are a treacherous hypocritical set of Yankees." Hawkins privately wrote that he was "done with missionary schools" and the "influence these missionaries

\footnotetext{
${ }^{14}$ The terms "mixed blood" and "full blood" present difficulties. Although most traditionalist Indians were indeed "full bloods" and many acculturated Indians were "mixed bloods," as historians have recently begun to argue, it was not quantum of blood, mixed or full, that determined Indian politics. In other words, it was resistance or willingness to adopt to white, Southern culture that defined these groups' politics, not blood. This also helps explain how certain figures such as John Ross, of mixed-blood heritage himself, could ultimately prove sympathetic to traditionalist causes. Still, contemporaries of the time often noted the blood-divide between the traditionalist and acculturated camps within the tribes. In this work, I have tried to avoid, where possible, using blood as a means of analysis and have instead focused on the issues of acculturation and in turn, Confederate alliance, that politically divided these groups. For more on the mixed-blood, full-blood divide as a poor means of analysis, see Theda Perdue, "Mixed Blood" Indians: Racial Construction in the Early South, Mercer University Lamar Memorial Lectures No. 42 (Athens: University of Georgia Press, 2003); William G. McLoughlin, After the Trail of Tears: The Cherokees' Struggle for Sovereignty, 1839-1880 (Chapel Hill: University of North Carolina Press, 1993): 154156.
} 
have over some of our Choctaw people." J.B. Hancock thought it best to monitor the missionaries closely, "lest they might incite your slaves to rebellion....and mature their diabolical plots of treachery." Slaveholder Robert Jones complained that missionaries too often "preach abolitionism.” The Choctaw and Chickasaw Indian agent, Douglas Cooper, warned in an 1860 report, "No doubt we have among us free-soilers; perhaps abolitionists in sentiment," although Cooper noted that those "who entertain opinions unfriendly to our system of domestic slavery, carefully keep their opinions to themselves.” Although writing in 1862, Cherokee missionary Stephen Foreman's diary conveys the passions the issue stirred amongst the pro-slavery camp. "I am a Southern man from principle, and have for some years been fighting the principles and practices of the abolitionist," Foreman confided to his journal, "and now since I have seen and felt the workings of abolitionism, I am ten times more opposed to it." Clearly, slavery and abolitionism were on the minds of both white and Indian Southerners. ${ }^{15}$

Adding to the hysteria was the possibility of abolitionist arms-dealing in the Territory. Missionary George Ainslie confessed that a fellow reverend had been arrested on the charge "that he was trafficking in arms-which unfortunately was true." Reverend C.B. Downing wrote to his superiors in New York that the arrested individual, "by selling revolvers secretly, has been 'suspected' of abolitionism." The panic was spilling over "among our Texas and Arkansas neighbors," Downing noted. However small the abolitionists' number, they were causing quite a stir and proving additional fuel for anti-abolitionist sentiment. Indeed, so concerned were Texans that soon armed mobs were striking into Indian Territory in search of abolitionists.

\footnotetext{
${ }^{15}$ George W. Hawkins to Peter Pitchlynn, October 19, 1853, Peter Pitchlynn Papers, Western History Collections, University of Oklahoma, Norman, OK, hereinafter referred to as WHC; J.B. Hancock to Peter Pitchlynn, Sept. 15, 1860, Peter Pitchlynn Papers, WHC; Report of the Commissioner of Indian Affairs for the Year 1858 (Washington: William A. Harris, 1858): 143; Joel D. Boyd, "Creek Indian Agents, 1834-1874," Chronicles of Oklahoma 54, no. 1 (1973): 46-49; Diary of Stephen Foreman, July 18, 1862, Stephen Foreman Papers, WHC. All emphasis in original documents.
} 
These actions, in turned, angered the Choctaws, whose sovereignty was violated by these acts of vigilante justice. The Choctaw reportedly held meetings "to organize and arm in home defense" in reaction to Texan incursions. The specter of abolitionism frightened Indian elites, worried fellow missionaries, angered white neighbors, and marred Indian-white relationships. ${ }^{16}$

Even Chief John Ross, who although a slaveholder was an ally of the traditionalist faction within the Cherokee tribe, worried about abolitionism. In his 1860 annual message, Ross lamented that "the subject of slavery has become paramount to all other considerations in opposite sections of the United States." Ross warned against agitation against slavery: "we should discountenance every thing of the sort, and not needlessly and unwisely disturb our own peace." The Southern Superintendent of Indian Affairs Elias Rector noted in his 1860 report that "great strife and contention" was brewing amongst the Cherokee. "Hostile parties have been organized, and, it is said, an extensive secret association formed among the full-bloods. Murders are continually committed..." Rector pinpointed the source of the trouble to "be the intermeddling, by the missionaries among them, headed by Evan and John Jones, with the institution of slavery." 17

Although John Ross declared that the slavery question was a "settled" one amongst the Cherokee, the reality was that abolitionism was increasingly a wedge dividing all of the Five Tribes. As Southern states seceded, Indians elites contemplated their connections with their Southern brethren, and the shared institution of slavery loomed large. The slaveholding elite clearly had a vested interest in ensuring that their property remained secure within a Southern

\footnotetext{
${ }^{16}$ George Ainslie to J. C. Laurie, July 13, 1861, American Indian Correspondence, Presbyterian Historical Society, hereinafter referred to as PHS; C.B. Downing to J.W. Wilson, April 27, 1861, American Indian Correspondence, PHS. All emphasis in original documents.

${ }^{17}$ Gary Moulton, ed. The Papers of Chief John Ross, 2 vols. (Norman: University of Oklahoma Press, 1984): 2, 450; Report of the Commissioner of Indian Affairs for the Year 1860 (Washington: George W. Bowman, 1860): 115-116.
} 
confederacy. While slaveholders may have represented a small fraction of the Indian population, they wielded enormous political power. Robert Jones, again utilizing his influence, argued passionately for secession in front of the Choctaw National Council in 1861. The Chickasaw Legislature declared that "our geographical position, our social and domestic institutions, our feelings and sympathies, all attach us to our Southern friends" in its declaration of independence in May, 1861. Furthermore, the Legislature warned of a war waged by the "Lincoln Government" that "will surpass the French revolution in scenes of blood and that of San Domingo in atrocious horrors." Missionary activity catalyzed the slavery discussion. ${ }^{18}$

Missionaries were not the only ones charting the course of Indian "civilization." Government-appointed Indian agents regularly reported to Washington, D.C. with their analysis of how the Five Tribes were progressing in Indian Territory. Mostly Southern and overwhelmingly pro-slavery in outlook, they worked tirelessly to bring the Five Tribes into the Confederate fold. In 1861, all five of the federally appointed Indian agents to the Five Tribes sided with the secession movement and urged the Indian tribes to ally with the Confederacy.

The Creek Indian agent, South Carolinian William H. Garrett, was a trusted figure among the tribe and helped pull the tribe into the war on behalf of the South. During his tenure, Garrett involved himself in the discussion about the efficiency of the Creek government. The Creeks, unlike several of the other Five Tribes, did not have a constitutionally constructed government. Garrett felt that the Creeks' "primitive form of government" suited them well, however, and felt that "education and association with the white man... will prepare them, at no very distant day,

\footnotetext{
${ }^{18}$ Angie Debo, The Rise and Fall of the Choctaw Republic (Norman: University of Oklahoma Press, 1934): 81; Official Records of the War of the Rebellion, 128 vols. (Washington, D.C., 1880-1902): v. 3, 585. Hereinafter referred to as the ORs; all citations refer to Series I. unless otherwise noted. The distinction between secession and alliance with the Confederacy is blurred. Several tribes seceded or declared independence prior to joining the Confederacy, following the same political path as many other Southern states. Nevertheless, the intention of all Five Tribes was to join the Confederacy, regardless of whether they took the preceding step of secession or not.
} 
for a more complicated form of government." The Creek Nation, located in the heart of Indian Territory, was also home to the Seminoles, who had been the last of the Five Tribes to arrive in the Territory. The Creeks and Seminoles clashed politically and socially with one another, largely over allegations of Seminole importation of liquor. Garrett recommended and oversaw the process of separation between the two tribes that resulted in the formation of the Seminole Nation (just west of the Creek Nation) in 1856. With the outbreak of secession and war in 1861, Garrett pushed the Creeks to ally with the Confederacy. When the Creeks did form such an alliance on July 10, Garrett even played a role in the formation of a Creek regiment of warriors for Confederate service, angling in part to lead the troops himself (he was denied the position). He would go on to serve in the Confederate army. ${ }^{19}$

The Seminoles' Indian agents proved influential among the tribe, helping convince the Seminoles that economic and social ties bound the tribe to the Southern cause. Josiah Washburne served as the Seminole Indian agent from 1853-57 and remained active among the Seminoles after that time. His replacement, Virginian Samuel Rutherford, saw the Seminole Nation through the secession crisis of 1861 . Both men were ardent secessionists and worked to bring the Seminole into the Confederate fold. Washburne had played a crucial role in securing the Seminoles status as an independent nation and was well-respected among the Seminole community. Although a Northerner by birth, Union agents believed that he was one of the most rabid secessionists in the Territory. As the Seminole Nation did not border Arkansas or Texas, Washburne was one of the few influential whites in the area pushing for secession. Washburne argued that the crumbling United States would be unable to pay the Seminoles their annual

\footnotetext{
${ }^{19}$ Report of the Commissioner of Indian Affairs for the Year 1858 (Washington: William A. Harris, 1858): 143; Joel D. Boyd, "Creek Indian Agents, 1834-1874," Chronicles of Oklahoma 54, no. 1 (1973): 46-49; Angie Debo, The Road to Disappearance: A History of the Creek Indians (Norman: University of Oklahoma Press, 1941): 142-143, 145.
} 
annuities and that the Confederacy, sure to have European support in its bid for independence, could guarantee the nation's political security. For his Southern loyalties, Washburne was recommended for a quartermaster command in a Confederate Indian regiment. Samuel Rutherford also supported secession, but instead focused on the shared institution of slavery and geographic links Indians had with the South. Never bothering to formally resign his U.S. post, he earned himself a recommendation as the Confederate Seminole Indian agent. ${ }^{20}$

The Choctaw and Chickasaw Nations shared an agent in Douglas H. Cooper, who had warned of "free-soilers" amongst these tribes in 1860. Cooper, a Mississippian who had served as an agent since 1853 , was a strong supporter of both slavery and the Confederacy and quickly rallied to the Southern cause. In May 1861, the Confederate Secretary of War Leroy Walker wrote to Cooper requesting that he "cultivate the most friendly relations and the closest alliance with the Choctaw Nation and all the Indian tribes" in the Territory. Walker pointed out the "unjust designs against the Indian country the Northern movement" had perpetrated. The Five Tribes "destiny has thus become our own," Walker determined. While the sweeping claims of Walker can be questioned, Walker did authorize Cooper to raise a regiment for Confederate service among the Choctaw and Chickasaw. Cooper commanded the $1^{\text {st }}$ Choctaw and Chickasaw Mounted Rifles for much of the war (the only non-Indian to command an Indian regiment) and eventually earned his brigadier general's stars serving the Confederacy. ${ }^{21}$

The Cherokees' Indian agent held the least sway among any tribal agent, fighting, as he was, the relative strength of the Cherokee tribe, the determined neutrality of John Ross, and reluctance of many traditional Indians to rush into a Southern alliance. The Cherokee Indian

\footnotetext{
${ }^{20}$ Thomas Elton Brown, "Seminole Indian Agents, 1842-1874," Chronicles of Oklahoma 51, no. 1 (1973): 72, 74-75; OR, v. 3, 598.

${ }^{21}$ Anne Bailey, "Douglas Hancock Cooper," The Confederate General, 2 vols. William C. Davis and Julie Hoffman, eds. (USA: National Historical Society, 1991): vol. 2, 26-27; OR, vol. 3, 574-575.
} 
agent at the time of secession, John Crawford, was an Arkansan hailing from Fayetteville. Crawford had voted against Lincoln in the 1860 election, and he supported the emergent Confederacy. Crawford threw his support behind Stand Watie and other elite Cherokees who supported secession. Yet Watie was not chief of the Cherokee; that position was held by John Ross, who remained determined throughout the summer of 1861 to keep his nation neutral. Thus, while the four tribes were allying with the South, the Cherokee maintained a position of neutrality until August. Crawford would continue to remain the Cherokee Indian agent under Confederate authorities. ${ }^{22}$

Taken collectively, the Indian agents to the Five Tribes, largely hailing from the South and decidedly pro-Southern in sentiment, played a role in convincing Indian elites of the wisdom of a Confederate alliance. Indian agents, especially those with long tenure such as Douglas Cooper and Josiah Washburne, were well-known, trusted, and respected figures amongst their respective Indian communities. In Seminole and Creek tribes, the Indian agents played a more decisive role in forging Indian-Confederate alliances, overcoming significant numbers of proneutral Indians among these tribes. Indian agents were cultural middlemen, schooled in both white and native culture, politics, and society. These agents utilized their positions in the summer of 1861 as platforms to push a pro-Confederate agenda, often emphasizing shared borders, similar social institutions including slavery, economic realities, and the inevitability of Southern independence to convince Indian elites and tribal governments that, as Secretary of War stated, the Five Tribes' "destiny has thus become our own."

Southerners did not need to have a federally-appointed post to interact with the Five Tribes or persuade Native-Americans why allying with the South was in their best interest. The 73): 451 .

${ }^{22}$ Carol B. Broemeling, “Cherokee Indian Agents, 1830-1874,” Chronicles of Oklahoma 50, no. 4 (1972- 
Five Tribes had white Southern neighbors in both Arkansas and Texas with whom they had longstanding relationships. These relationships transformed into conduits for political and ideological exchanges in the crisis of 1861, channels by which Indian and Southern ties could be strengthened.

Indian Territory was closely linked economically and, to a lesser extent politically, to Arkansas and Texas. It is worth noting that while only $4 \%$ of the Indian Territory's population was white, that white population was overwhelmingly Southern $(75 \%)$, with the largest contingent hailing from the Upper South. Of course, this makes sense geographically, especially when one considers that Indian Territory lay along several important routes for Southwestern emigration. Moreover, while missionaries may have exerted some influence, especially in regards to the slavery question, they were relatively few in number. As scholars have pointed out, most Indian interaction and acculturation occurred with everyday white Southerners. ${ }^{23}$

Two vital arteries connected the Indian Territory to its neighbors - the Arkansas and Red River Valleys. The Arkansas River connected Cherokee Nation to Fort Smith, Little Rock, and the Mississippi River. The Red River, running along the Texas-Indian Territory border, was perhaps the more vital artery of the two as it cascaded down through Louisiana to New Orleans and the Gulf of Mexico. The Choctaw and Chickasaw Nations, located in southern Indian Territory and bordering Texas and the Red River, benefited most from the river trade.

Copies of the Choctaw Intelligencer from the 1850's bear witness to the extensive trade plied all along the Red. Advertisements hawked dry goods, groceries, books, stationary, boots, saddles, medicine and more. Virtually all of the advertisements represented warehouses and stores along the Red River, in Shreveport and New Orleans. The Cherokee Advocate promoted goods in Van Buren, Cane Hill, and other towns in Arkansas near the Territory border. Not just

\footnotetext{
${ }^{23}$ Doran, "Population Statistics," Chronicles of Oklahoma, 501-502.
} 
goods traversed the waterways and roads of the region, of course. News certainly did as well. The Cherokee Advocate, somewhat more urbane than the Intelligencer, featured the latest from papers and journals such as the Chambers Edinburg Journal, Philadelphia Inquirer, and the Annals of Education. Local news and announcements, such as dates for temperance society meetings or the funeral of a Freemason, were sure to be found. Yet editorials as well as national and international news also appeared in print. The Saturday, November 9, 1844 edition of the Advocate, for example, contained not just local news, but the latest from the Republic of Texas, Siberia, and Morocco. The contents of these papers, both news and advertisements, reveal both local and long-distance networks of economic, informational, and ideological exchange. ${ }^{24}$

Neighbors, of course, knew one another more intimately. Whites and Indians intermarried, despite attempts to regulate such behavior. In 1855, the Cherokee Nation passed a law regulating marriage between Cherokee women and white men. Concerned with white men gaining access to the abundant resources of the Territory, white men needed governmental permission to marry Cherokee women. Still, intermarriage between whites and Indians occurred, and families had kin on the other side of the border. ${ }^{25}$

As Southern states began to secede, Arkansans and Texans cast a keen eye over Indian Territory, wondering what course their Indian neighbors would pursue. It was an important question, for Indian Territory served as a buffer region, lodged on Arkansas' western flank and shielding North Texas from jayhawker Kansas. Future Confederate Commissioner of Indian Affairs David Hubbard, sent as a secessionist commissioner to Arkansas in January 1861, noted some Arkansans' anxiety regarding secession without an understanding that the Five Tribes would move in a congruent fashion. The Arkansas state government was unwilling to secede as

\footnotetext{
${ }^{24}$ Choctaw Intelligencer, October 18, 1851; Cherokee Advocate, September-November, 1844.

${ }^{25}$ Fay A. Yarbrough, Race and the Cherokee Nation: Sovereignty in the Nineteenth Century (Philadelphia: University of Pennsylvania Press, 2008): 57-59.
} 
"the people have not yet made up their minds to go out." "The [Arkansas] counties bordering on the Indian Nations, Creeks, Cherokees, Choctaws and Chicasaws [sic]," Hubbard reported, "would hesitate greatly to vote for secession, and leave those Tribes still under the influence of the Government at Washington, from which they receive large stipends and annuities." Hubbard recognized the importance of Indian Territory: "These Indians are at a spot very important, in my opinion, in this great sectional controversy, and must be assured that the South will do as well as the North, before they could be induced to change their allegiance and dependence." The geopolitical importance of Indian Territory, and the allegiance of its denizens, was not lost on Arkansas. ${ }^{26}$

Texans, and especially the citizens of North Texas settlements, watched their Native American neighbors to the north (especially those in the bordering Choctaw and Chickasaw Nations) intently and proved more proactive in affairs in Indian Territory. The counties of northcentral Texas constituted a small pocket of Unionism amidst a sea of secession in 1861. In Texas' February, 1861 referendum, eight north Texas counties had voted to remain in the Union. North Texas had relatively little to gain from secession. Many farmers relied upon sales of wheat and corn to government agencies in Indian Territory, and just like their fellow Arkansans, North Texans worried about the proximity of Indians and possible Federal invasion across the border.

As has already been mentioned, Texan mobs proved themselves willing to violate Indian sovereignty in search of abolitionists. Reverend John Edward's experience with these marauding

\footnotetext{
${ }^{26}$ William R. Smith, "Report of Hon. David Hubbard, Commissioner to Arkansas," The History and Debates of the Convention of the People of Alabama (Atlanta, GA: Wood, Hanleiter, Rice \& Co., 1861): 443-444; Annie Heloise Abel, The American Indian as Slaveholder and Secessionist (1915; repr., Lincoln: University of Nebraska Press, 1992): 108-110. David Hubbard, from Alabama, was one of many secession commissioners roaming the South in 1861. These men sought to convince other Southern states that their best interests lie in leaving the Union and joining the Southern Confederacy. For more on secession commissioners, read Charles B. Dew's Apostles of Disunion (Charlottesville: University of Virginia Press, 2001).
} 
mobs is perhaps representative. He reported that a "company of Texans" arrived at his home "to search for revolvers." The Texans not finding any (for Edwards had none), then wanted to know "if Edwards was with the South" and should war erupt, if he "would take up arms for the South." Unable to "pledge myself to that," Edwards left the Territory as soon as possible. In this instance, Texans used searching for weapons as a pretense to remove any Territorial residents who did not possess pro-Southern sentiments. ${ }^{27}$

In April 1861, Texans increased their pressure on the Territory by seizing abandoned U.S. army forts in the Choctaw and Chickasaw Nations. These violations of Indian sovereignty and the close proximity of armed Texans made some Indians uneasy. Choctaw Sampson Folsom wrote in May that he found "our lovely country in the hands of Texanian [sic] filibusters. They are making inroads upon our soil...making war upon the old missionaries of the Country." Folsom felt confident that the Texans had an ulterior motive. "What they will do next," he determined, "is make white settlement our midst." Folsom had a radical solution: "I am for raising five thousand Choctaws and Chickasaw troops at once to keep out Land Pirates and abolitionists." Texans were securing their interests by force, and it threatened Indian-white harmony. $^{28}$

Yet the Texans' forceful tactics, however offensive to some, worked. As the secession crisis grew, the proximity and pressure of Texans pushed the Chickasaw Nation to make their decision, and the Nation allied with the South on May 25. The Choctaw Nation, however, grappled with the issue longer. Peter Pitchlynn, a highly influential member of the Choctaw elite, favored neutrality. As a mid-June meeting of the Choctaw Council loomed, Pitchlynn attempted to convince the Choctaw Principal Chief George Hudson that neutrality was the best

\footnotetext{
${ }^{27}$ John Edwards to J.L. Wilson, May 24, 1861, American Indian Correspondence, PHS.

${ }^{28}$ H. Balentine to J.L. Wilson, May 6, 1861, American Indian Correspondence, PHS; Sampson Folsom to Peter Pitchlynn, May 14, 1861, Peter Pitchlynn Papers, WHC. All emphasis in the original documents.
} 
option. Hudson seemingly agreed. For Texans, the possibility of Choctaw neutrality was unacceptable. A Texan vigilance committee crossed into Choctaw Nation, surrounded Pitchlynn's home and damned him as an abolitionist. Threats were made on Pitchlynn's safety should he persist in his neutral stance. When the Choctaw Council finally met, it was "full of white men" from Texas, who met privately with Choctaw elites to ensure that secession followed. As the meeting began, Robert M. Jones spoke first, proclaiming that any who opposed secession ought to be hanged. With approving Texans looking on, George Hudson was thoroughly cowed, and the Choctaw Nation seceded. ${ }^{29}$

It is doubtful secession reflected the opinions of all, if even a majority, of the Choctaw people. Reverend Copeland opined of that the "Choctaws \& Chickasaws are trying to be quiet and take no part or lot in the strife" and that "some [are] wishing to secede, but the majority opposed to secession for the present." Another missionary, Orlando Lee, reported much reluctance among the Choctaw regarding secession. He wrote that some Choctaws told him, "If the north was here so we could be protected we would stand up for the north but now if we do not go in for the south the Texans will come over here and kill us." Furthermore, Lee indicated that traditionalist Indians "were strongly for the north," but eventually "yielded to the pressure" and joined the pro-Southern ranks. ${ }^{30}$

Certainly, there were many Choctaws who were loyal to the South and viewed southerners and Texans as their brethren. At an assembly of Choctaw warriors on July 4, 1861, an old warrior delivered a speech under a Confederate flag. The Standard, published in

\footnotetext{
${ }^{29}$ Clayton E. Jewett, Texas in the Confederacy: An Experiment in Nation Building (Columbia: University of Missouri Press, 2002): 83; W. David Baird, Peter Pitchlynn: Chief of the Choctaws (Norman: University of Oklahoma Press, 1972): 162-127.

${ }^{30}$ C.C. Copeland to J.L. Wilson, April 18, 1861, American Indian Correspondence, PHS; C.C. Copeland to J.L. Wilson, May 2, 1861, American Indian Correspondence, PHS; Orlando Lee, quoted in Abel, American Indian as Slaveholder and Secessionist, 77-78.
} 
Clarksville, Texas, carried the report. "Warriors of the Choctaw and Chickasaw Nations!" the old Indian began. "Who are these men? Your brothers - the men of the South-men who have come from the land of sunshine across Red River-whose star is in the centre [sic] of your flag, and who are in our hearts." The warrior called upon the Indians to fight like Texans: "You, men and warriors, must emulate their glorious deeds." These words were met with "deafening shouts from the warriors." ${ }^{31}$

Over a month later, a Texas artillery soldier wrote the Dallas Herald of his experience marching through Indian Territory. "We made a rapid march through the Chickasaw and Choctaw nations, and found them both loyal to the South...[W]e came up with regiment of Indians, who seemed keen for a fight with the Abolitionists." The soldier continued, "I asked an Indian warrior who could speak but little English, 'of what tribes the regiment was composed"" and was told initially told "'Choctaw, Chickasaw and white men." However another Indian made an alteration, declaring “"Oh no, Choctaw, Chickasaw and Texan!” The soldier wrote, "I cite this as an incident illustrating how thoroughly these Indians have identified themselves with the South, and especially with the people of Texas." In a similar incident, as the Third Texas Cavalry passed through Boggy Depot, Choctaw Nation that July, local Choctaw ladies presented them with a flag. ${ }^{32}$

It is difficult to assess the true sentiments of the Choctaw Nation. While many Choctaw supported the Confederacy and served in its ranks, there was clearly a minority, perhaps even a silent majority, who supported a neutral or pro-Union stance. Either way, the historical silence of whatever pro-neutral Choctaw camp existed is due to the work of Texans, who used threats of violence and sheer peer pressure to ensure that no serious debate over secession occurred. Texan

\footnotetext{
${ }^{31}$ The Standard [Clarksville, TX], July 20, 1861.

${ }^{32}$ Dallas Herald, vol. 9, no. 46, August 21, 1861; Douglas Hale, The Third Texas Cavalry in the Civil War (Norman: University of Oklahoma Press, 1993), 51.
} 
citizens were not just mindful of events in Indian Territory, but were proactive in shaping those events.

What encouraged Texans to resort to force? While the Five Tribes in the Territory may have enjoyed harmonious relations with their Texan neighbors, other Indian tribes did not. The nomadic Plains Indians, particularly the Comanche, did not respect Confederate authority and raided the Texan frontier both before and during the Civil War. Thus, frontier Texans had constant experience with Indian violence; perhaps looming war blurred the distinctions between “civilized" and "savage" Indians.

Adding to the traditional fear of Indian raids, the summer of 1860 brought fears of a slave insurrection. While the details remain uncertain, scholars have concluded that slaves, perhaps aided by abolitionists, committed serious acts of arson in a variety of Texan towns, destroying over one million dollars in property. The plot brought attention to abolitionist activities, which in turn drew eyes north of the border. The Daily Crescent reported that once the plot rendered the region "helpless," insurrectionists would receive aid "from the Indians and Abolitionist." Ultimately, there is no evidence to suggest any Indian participation in the plot, and few papers charged Indians of involvement. Yet undoubtedly the plot had Texans on edge. It is unsurprising, then, that Texan mobs would soon roam Indian Territory in search of abolitionists. Threatening raids from the Plains tribes and the fear of slave insurrections helped spur Texans to take matters into their own hands when yet another crisis - this time in the form of Indian secession-arose in $1861 .^{33}$

Other citizens took a less brash approach of bringing Native Americans into the Confederate fold. The fate of the Cherokee Nation, one of the more powerful of the Five Tribes,

${ }^{33}$ William W. White, “The Texas Slave Insurrection of 1860," The Southwestern Historical Quarterly 52, no. 3 (Jan., 1949): 260, 262, 285. 
drew the attention of many. Chief John Ross, who led the Cherokee into a position of neutrality early in 1861, constantly fielded letters from white neighbors both requesting and demanding to know his intentions. In January 1861, Arkansas Governor Henry Rector wrote John Ross to inform him that "the incoming administration of Mr. Lincoln" saw Indian Territory as "fruitful fields, ripe for the harvest of abolitionists, freesoilers, and Northern mountebanks." Rector assumed the Cherokees' course of action, noting that, "We hope to find in your people friends willing to co-operate with the South in defense of her institutions, her honor, and her firesides." Ross responded deftly, pointing out both Cherokee treaties with the United States and that Cherokee "institutions, locality \& natural sympathies are unequivocally with the slave holding States." A clever non-answer, Ross never committed to any Southern alliance. ${ }^{34}$

More letters poured in. In May, citizens of Boonsboro, Arkansas wrote Ross to learn of Cherokee intentions, noting they preferred "an open enemy to a doubtful friend." Ross replied with his "friendship for the People of Arkansas" but noted that "if my present position does not constitute us 'as active friends,' as you might desire us to be, you will surely not regard us as an enemy." Again, Ross took a position of "strict neutrality." Thus, from both the Governor and everyday citizens, Arkansans sought to uncover the intentions of their Cherokee neighbors, hoping to convince John Ross of the wisdom of an alliance. ${ }^{35}$

Confederate General Benjamin McCulloch, tasked with defending Indian Territory, took a different approach while writing to Ross in June. Professing that Cherokee neutrality "will not be molested without good cause," McCulloch then requested that pro-Confederate Cherokees be allowed to "organize into military companies," ostensibly for protection from Northern invasion.

${ }^{34}$ OR, vol. 1, 683-684; Moulton, Papers of Chief John Ross, vol. 2, 464-465.

${ }^{35}$ Mark Bean et. al, quoted in Gary Evan Moulton, "John Ross, Cherokee Chief” (PhD diss., Oklahoma State University, 1974), 306; Confer, Cherokee Nation in the Civil War, 43; Moulton, Papers of Chief John Ross, vol. 2, 470-471. 
John Ross understood that arming Confederate Cherokees would undercut any claims to Cherokee neutrality. Ross answered resoundingly. "We have done nothing to bring about the conflict in which you are engaged with your own people, and I am unwilling that my people shall become its victims." Regarding arming Cherokees as home guards, Ross "most respectfully declined." No neighbor, whether government official, civilian, or general, could budge Ross on his position of neutrality. ${ }^{36}$

White neighbors of Indian Territory both anxiously watched and participated in the Indian decision-making process in the summer of 1861. Arkansans worried over their western frontier and thought about the ramifications of secession without Indian allies. Texans proved more forceful, unafraid of using threats of violence in the process; they ensured that their neighbors to the north would ally with the South. Yet despite the outpouring of letters from all rungs of society asking the Cherokee to join with the Confederacy, John Ross remained firm in neutrality. If white pressure couldn't budge Ross politically, however, Indian pressure could. Throughout 1861, while missionaries stirred up fears of abolitionism, Indian agents switched sides, and neighbors pressured neighbors, Indians had their own internal discussions about which course to pursue. Geopolitical realities, old political and cultural cleavages within Indian society, and competing visions of the future all had to be confronted by each of the Five Tribes.

The United States military's evacuation of Indian Territory in the spring of 1861 profoundly shaped Native American decision making in the subsequent months. While pressure poured in from all sides for the Five Tribes to ally with the South, the U.S. government and its military were absent and silent. Grappling with greater crises around the country, the United States violated its treaty obligations and left Indian Territory both unprotected and vulnerable to Confederate advances. Diplomatically, there was no counter-weight to Confederate influence.

\footnotetext{
${ }^{36}$ OR, vol. 3, 591-592, 596-597.
} 
As the Choctaws had said, "If the north was here so we could be protected we would stand up for the north." But the North was not there, and the young Confederacy worked hard to fill the power vacuum left behind by the retreating United States. Undoubtedly, that decision to retreat loomed large in the minds of Indian leaders and citizens alike. ${ }^{37}$

Moreover, Indian Territory was strategically placed between Texas and Arkansas. Especially for the Chickasaw and Choctaw, continued allegiance to the United States or neutrality must have seemed futile and possibly dangerous, with Confederate authority so close. To a certain extent, a domino effect began to occur. First the Chickasaw, then, albeit with a Texan push, the Choctaw allied with the Confederacy. Suddenly, the Confederate borders with the Cherokee, Creek and Seminole Nations grew. Forts in southern Indian Territory were now held by Confederate Texan troops. E.H. Carruth reported that Chief John Jumper of the Seminoles was torn by the circumstances around him. "He felt true to the [U.S.-Seminole] treaties, \& said that all his people were with the Government," Carruth reported, "but, the Forts west were in possession of its enemies, their Agent would give them no information on the subject, \& he feared that his country would be overrun, if he did not yield." For John Jumper and the Seminoles, the Confederates were knocking on the door, and the United States was nowhere to be found. It is no wonder that they allied with the Confederacy. ${ }^{38}$

The United States' departure in 1861, and the subsequent advance of the Confederacy, highlight the how the war had shattered the relative stability of the Indians' homeland and transformed it into a tumultuous borderland. Prior to 1861, Indian Territory served as the new home for the Five Tribes, a place where they could attempt to rebuild their world in a western locale. While western Plains Indians and political feuds occasionally jarred the political

\footnotetext{
${ }^{37}$ Orlando Lee, quoted in Abel, American Indian as Slaveholder and Secessionist, 77-78.

${ }^{38}$ E.H. Carruth, quoted in Abel, American Indian As Slaveholder and Secessionist, 85, footnote 122.
} 
landscape, by and large these Indians enjoyed a relative degree of sovereignty and security under the protection of the United States, who occupied a variety of military posts in the region. Secession and U.S. retreat turned that frontier into, in effect, a vacuous borderland where chaos, fear, insecurity, and violence began to reshape the region's allegiance and, in turn, its future.

By the beginning of August, the option of neutrality was fast dwindling; only two neutral parties remained. One was the Cherokee Nation led by John Ross. The other was a growing band of neutral, pro-Union, and anti-Confederate dissidents led by several Creek chiefs, notably Oktarharsars Harjo (known to whites as Sands) and Opothleyahola. The Creeks had long been riven into two wings: a traditionalist faction, among whom Sands and Opothleyahola were leaders, and the acculturated elites headed by brothers Chilly and Daniel McIntosh. The McIntoshes spearheaded the successful effort to forge a Creek-Confederate alliance, and the traditionalist Creeks spurned the arrangement. On August 5, a body of full-blood Creeks loyal to the United States met and declared their Nation's treaty with the Confederacy illegal and asked President Lincoln for protection. Communication with Washington was a nightmare; again, agents of the United States were not on hand for advice or assistance. In November, a delegation of chiefs went to Kansas, where they discovered new U.S. Indian agents had been appointed to treat with them. Sands was able to convey that twenty-seven towns and 3,350 warriors remained loyal to the Union. Unable to provide any meaningful assistance, Federal officials in Kansas sent the delegation to Washington, D.C. to view the fortifications around the capital and meet with President Lincoln. It was an empty gesture that gave no meaningful support to loyal Indians in Indian Territory. ${ }^{39}$

${ }^{39}$ Debo, The Road to Disappearance, 147-149; Edwin C. Bearss, "The Civil War Comes to Indian Territory, 1861: The Flight of Opothleyahola," Journal of the West 11 (Spring, 1972): 8-9. 
While Unionist Creeks and other dissidents gathered under Opothleyahola along the North Fork River, John Ross confronted the increasing tenuous diplomatic and political situation the Cherokee Nation faced. He owed most of his troubles to the machinations of Stand Watie. Watie and Ross were old rivals, part of a feud dating back to Cherokee removal in the 1830's. Watie had belonged to the so-called Treaty Party, which had signed the Treaty of New Echota in 1834. A fraudulent document, it had allowed a small minority of elite Cherokees to sign away all Cherokee-held lands in the East. The general meeting which approved the treaty had been attended by roughly $2 \%$ of the Cherokee population. John Ross, chief of the Cherokees then as well, fought and failed to have the treaty overturned, and it was passed through the United States Congress by a single vote. The resulting Trail of Tears not only ripped the Cherokees from their ancestral homelands, but also tore apart their society into two warring factions. Leaders of the Treaty Party were assassinated, and murder became commonplace in the Cherokees' newfound land in the West. Only a peace agreement in $1846 \mathrm{kept}$ the Cherokee from breaking into open civil war. ${ }^{40}$

Stand Watie and John Ross were authors of that feud. Moreover, each represented disparate wings of the Cherokee Nation: Watie symbolized the wealthy, acculturated elite who envisioned themselves as Southerners; Ross was the champion of the poor, traditional Cherokee masses. Watie and his party, then, had little use for Ross' declarations of neutrality. At the same time that Ross was convincing Southern neighbors of the Cherokees' neutrality, Watie communicated with various Confederate officials about arming his party for Confederate service. Letters from citizens in Fayetteville, Arkansas, promised Watie weapons and inquired into his "feelings and intentions in the present state of war." In mid-July, Confederate General Benjamin

\footnotetext{
${ }^{40}$ Conifer, Cherokee Nation in the Civil War, 20-23.
} 
McCulloch commissioned Watie a colonel in the Confederate army. Watie soon had a force of three hundred armed men under his command. ${ }^{41}$

In August, Stand Watie's close friend and fellow Treaty Party member William Adair wrote Watie, asking that he meet with Confederate General Albert Pike so that, "we may have justice done us, have this pin party [a reference to the Keetowah Society] broken up, and our rights, provided for and place us if possible at last on an honorable equity with this old Dominant party [Ross' Party] that has for years had its foot upon our necks." ${ }^{42}$ Watie and his followers were armed, working with the Confederate military, and undercutting Ross' neutrality.

John Ross, aware of Watie's maneuvering, also had to take stock of military matters in the borderlands. General McCulloch, unable to persuade Ross to join the Confederacy, was taking matters into his own hands. Earlier in the summer, McCulloch petitioned the Confederate government for permission to invade Kansas, a move that McCulloch felt was the "only way to force his [Ross'] country into the Confederacy." His request was granted, giving him freedom to strike into Kansas or Missouri as he saw fit, setting the stage for conflict. On August 10, Confederate forces under General McCulloch and Missouri General Sterling Price decisively defeated Union troops at the Battle of Wilson's Creek in southwest Missouri. Fighting alongside the Southerners were small band of Cherokee "half-breeds;" undoubtedly some of Watie's men, although Watie himself was not present. This Southern victory, paired with news of Federal defeat at Bull Run outside of Washington, D.C., weighed on Ross' mind. ${ }^{43}$

${ }^{41}$ Edward Everett Dale \& Gaston Litton, Cherokee Cavaliers: Forty Years of Cherokee History as Told in the Correspondence of the Ridge-Watie-Boudinot Family (1939, repr.; Norman: University of Oklahoma Press, 1995): 106-107; Confer, The Cherokee Nation in the Civil War, 55.

${ }^{42}$ Dale and Litton, Cherokee Cavaliers, 108-109.

${ }^{43}$ William Garrett Piston \& Richard W. Hatcher III, Wilson's Creek: The Second Battle of the Civil War and the Men Who Fought It (Chapel Hill: University of North Carolina Press, 2000): 92, 101; Kenny A. Franks, Stand Watie and the Agony of the Cherokee Nation (Memphis: Memphis State University Press): 118; OR, vol. 3 , 54, 594. William G. Piston and Richard Hatcher's Wilson's Creek offers the best overview of this early Civil War campaign in Missouri. 
Other tribes' alliances with the South, Stand Watie's intransigent refusal to respect neutrality, and Confederate victories at Wilson's Creek and Bull Run finally convinced Chief John Ross that the Cherokees' fortunes lie with the South. Ross proved himself incredibly resilient to outside pressure; only glaring geopolitical realities and the desire for Indian unity in the Territory changed Ross' thinking. In an address to some four thousand Cherokees on August 21, Ross reminded the Cherokees that Indian Territory was their home. "When your nationality ceases here," Ross declared, "it will live nowhere else. When these homes are lost, you will find no others like them." Ross acknowledged the seeming reality of the current state of affairs. "The permanent disruption of the United States into two governments is now probable. The State [Arkansas] on our border and the Indian Nations about us have severed their connection from the United States and joined the Confederate States. Our general interest is inseparable from theirs and it is not desirable that we should stand alone." Having outlined the situation, Ross took the final step and asked the people to "signify your consent...for an alliance with the Confederate States." That alliance was formalized a little over a month later in Tahlequah, when Ross and Watie shook hands. ${ }^{44}$

With John Ross and the Cherokees in the Confederate fold along with the rest of the Five Tribes, Ross worked to bring Opothleyahola, Sands, and the wayward neutral Creeks into Confederate alignment as well. When John Ross informed the loyal Creeks on August 24 of the Cherokees' alliance with the Confederacy, Opothleyahola and Sands didn't believe the author of the letter was Ross. Assurances came from Ross the he was indeed the author, and he stated his desire "for all the red Brethren to be united" in alliance with the Confederacy. Despite Ross' attempts, Opothleyahola and his followers, growing by the day, remained loyal to the Union. ${ }^{45}$

\footnotetext{
${ }^{44}$ Moulton, Papers of Chief John Ross, vol. 2, 481-482.

${ }^{45}$ Ibid., 482, 488.
} 
By September 1861, the Cherokees, Creeks, Choctaws, Chickasaws, and Seminoles had all broken their ties with the United States and formed alliances with the Confederacy. These alliances were the products of diplomatic, political, and cultural exchanges that took place throughout Indian Territory and with its neighbors in 1861. Abolitionist missionaries sparked internal rifts among the Cherokee by helping establish the Keetowah Society, which in turn sparked a much larger fear of abolitionism throughout the region. Fueling fears of abolitionism were Indian agents, who urged the Five Tribes to follow the South down the road of secession. White neighbors in Arkansas and Texas also worked to sway the Five Tribes politically. Arkansans worried, and asked, what course their Indian neighbors would pursue. Texans, determined to secure their own borders, violated the borders of others. They arrested suspected abolitionists, pushed out missionaries who did not display pro-Southern sentiments, seized abandoned U.S. forts in Indian Territory, and used the threat of violence to silence dissent within the Choctaw Nation. The complete absence of the United State authority offered NativeAmericans no real alternative to Confederate alliances or attempts at neutrality. One by one, elite-controlled governments of the Five Tribes succumbed to pressure, recognized geopolitical realities, and allied with the emerging Confederacy. Not even stubborn John Ross could deny that the Five Tribes' fate was aligned with the South.

Yet cracks in these Indian-Confederate alliances existed from the very beginning. While borderland exchanges may have convinced Indians elites that their interests were intertwined with those of the South, traditionalist Indians remained unconvinced. Indeed, the very need for external pressure - from missionaries, Indian agents, or neighbors—underscores the lack of conviction among many Indians regarding the wisdom of joining the Confederacy. The Cherokee Keetowah Society resisted elite domination and served as a tool for pro-Union and 
abolitionist sentiments. Neutral and pro-Union sentiments among the Choctaw were crushed by Texan threats. Any thoughts of continued loyalty among the Chickasaw and Seminole were undermined by the proximity of Texan troops. For leaders like Cherokee John Ross, Choctaw Peter Pitchlynn, and Seminole John Jumper, alliance with the Confederacy became the only option, however more alluring neutrality seemed. Convincing and coercing was needed to forge alliances on paper, but these alliances did not always seep down to the hearts and minds of traditionalist majorities of the Five Tribes. It is quite possible that a majority of Indians did not, in fact, support secession and alliance with the South, although gaps in the historical record will leave that question unanswered.

Perhaps most indicative of the weakness of the Indian-Confederate alliances were the thousands of followers who gathered under Opothleyahola's leadership in the fall of 1861. Estimates range regarding the size of Opothleyahola's band; some figures place the number as high as 10,000, although a more reasonable estimate is approximately 5,000. At least 1,500 of this number were warriors; several hundred of these warriors were blacks, both free and enslaved. While Creeks and Seminoles comprised the bulk of the party, members of other tribes could be found as well. If estimates are correct, than nearly $9 \%$ of the Indian Territory's population had voted with their feet, spurning Southern alliances and leaving their homes to join Opothleyahola in his stand for neutrality. Opothleyahola's band was not abolitionist; in fact, Opothleyahola was one of the largest slaveholders in Creek Nation. Instead, these Indians rejected the premise that Indian and Confederate interests were intertwined, and they sought neutrality in the coming conflict. Southern cajoling and coercion failed to convert these Indians, mostly traditionalists, to the Confederate cause. Unwilling to be silenced, Opothleyahola and his followers were a nucleus of anti-Confederate dissent, a crack in the foundation that would only 
grow with the fires of war. By 1862, defection and desertion would decimate the ranks of Confederate Indians, a further indication that pro-Confederate feelings were not heartfelt. ${ }^{46}$ In some respects, Indian reticence to join the Confederacy mirrors that of the other border states-Missouri, Kentucky, Maryland, and Delaware - that grappled with secession and civil war in summer of 1861. As William Harris has noted, border state residents often enjoyed links to both the north and south that left them in a difficult position upon the onset of hostilities. Proximity to major urban centers, diverse populations, and fear of their homelands turning into battlegrounds encouraged some to remain loyal to the Federal government. The institution of slavery, hostility to abolitionism, and cultural ties bonded border residents to the South. Native Americans shared many of these sentiments. Many Indians' desire for neutrality is indicative of fear over the devastation that war would bring. Indian Territory, of course, also enjoyed a diverse population, not only in the presence of three different races and a multitude of Indian tribes, but also in the traditionalist and acculturated factions that divided every tribe. This population diversity would make it difficult for the Confederacy to unite all Indians under the Southern banner. Slavery, although entrenched among the Five Tribes, remained limited, with slaves comprising a small portion of the population (14\%) similar to that of Southern border states, rather than the Upper or Deep South. Still, the Five Tribes clearly were integrated into a borderland that was Southern in nature. It was with Texas, Arkansas, and Louisiana, not Kansas or Missouri, that Indians traded for goods, exchanged news, and shared similar institutions, particularly slavery. ${ }^{47}$

\footnotetext{
${ }^{46}$ Minges, Slavery in the Cherokee Nation, 111-112, 114-115; Bearss, "The Civil War Comes to Indian Territory," Journal of the West, 11; Opothelyahola File, Oklahoma Historical Society. The Seminoles in Opothleyahola's band were led by Halex Tustenuggee. The figure of $9 \%$ utilizes the 1860 population of Indian Territory, excluding the small population of whites, and was based upon an estimate that Opothleyahola's band numbered 5,000.

${ }^{47}$ William C. Harris, Lincoln and the Border States: Preserving the Union (Lawrence: University of Kansas Press, 2011): 2
} 
If the Five Tribes shared these northern and southern links with their fellow border states, then clearly the Territory had its own peculiarities and distinctions. The most obvious, of course, is that unlike Kentucky, Missouri, Maryland, and Delaware, the Five Tribes ultimately did cast their lot with the Confederacy. As has been shown, this was largely the result of immense borderlands pressure and a one-sided geopolitical situation that favored the Confederacy. Most importantly, wealthy, acculturated, slaveholding Indian elites saw their own interests as intertwined with the Confederacy. It was this pressure that pushed Indian Territory—despite its similarity to the Border South—into a Confederate alliance. Yet this border state comparison also helps explain why so many Indians' loyalty to the South would prove dubious at best. As historian William Freehling has argued, the Southern border states contributed relatively little to the Confederate cause, which "seriously compromised Confederate military manpower." Despite border state whites constituting 37 percent of the South's population, only 10 percent of these whites would serve in Confederate uniform. Moreover, border state whites enlisted in the Union army at a rate of 2-to-1 over the Confederate army. Despite their Southern links, border states by and large proved unwilling to cast their lot with the South. And while political machinations, external pressure, and internal elites may have led Indian Territory into the Confederacy, the persistent desire of neutrality and the sizeable anti-Confederate gathering under Opothleyahola all suggest that the anti-Confederate strains found in other border states also existed within the Five Tribes of Indian Territory. ${ }^{48}$

Ultimately, borderlands interactions profoundly shaped the way mixed-blood, elites viewed the looming Civil War. Feeling pressure from all sides, one-by-one these elites led the Five Tribes' governments out of the Union and into alliances with the Confederate States. Much of the responsibility for that decision rested not only among Indian elites themselves, but also

\footnotetext{
${ }^{48}$ Freehling, The South vs. The South, 61.
} 
among the missionaries, Indian agents, and Arkansan and Texan neighbors who worked tirelessly to ensure that the Five Tribes' future was intertwined with that of the nascent Confederacy. While these political and cultural exchanges shaped Native-American elites, however, they were far less persuasive to full-blood traditionalists. Indeed, old feuds over removal and acculturation simply found new fuel in debates over slavery and Southern alliances. Elites and traditionalists imagined different futures for their new homelands in the West. Elites saw themselves as part of wider, slave-holding South and allied with the Confederacy accordingly. Traditionalists rejected this premise and instead viewed the promise of neutrality as the best course of action. Formal alliances could not paper over these deep differences. These deep schisms within the Five Tribes revealed themselves, and by the autumn of 1861, the Five Tribes found themselves on the precipice of their own Civil War. 


\section{Chapter Two: Fight and Flight}

Although all Five Tribes aligned with the Confederate States in 1861, Confederate-Indian treaties rested upon a shaky foundation. With political, social, and even martial pressure bearing in from all sides, Indian elites pushed through Confederate treaties with which a large number of traditional Indians dissented. This voice of dissent, smothered in the summer heat of 1861, could not be contained as time wore on. Traditionalist Indians who once desired neutrality were now pushed into Unionism, and these Union Indians — men, women, and children — all coalesced around the Creek chief Opothleyahola in the fall and winter months.

Confederate leaders could not accept Opothleyahola's intransigence. The Creek chieftain's presence undermined Confederate power among the Five Tribes and threatened to weaken support for the Southern cause by offering full-bloods a Unionist sanctuary. Determined to crush Opothleyahola's opposition, the Confederacy launched a military offensive in the winter of 1861 that drove thousands of Unionist Indians out of the Territory and caused untold suffering. The offensive, however, failed to prevent schisms from growing among the Five Tribes, particularly the Creeks, Seminoles, and Cherokees. In short, although early battlefield victories gave the Confederates undisputed military control over Indian Territory, it weakened their political control.

This Confederate campaign against Opothleyahola has largely been forgotten by Civil War historians. A minor military affair on the far western border, it perhaps seems to merit little attention. But upon closer examination of the 1861 Confederate offensive in Indian Territory, it becomes clear historians can learn much from this dusty footnote in American history. The campaign against Opothleyahola radically altered the war in the Confederate borderlands. The Cherokee tribe, with whom the Confederacy had worked so hard to ally, quickly splintered as the 
campaign progressed, proving that for many poor, traditional Indians, loyalty to the Confederate cause was feeble at best. Moreover, the exile of thousands of Unionist Indians into Kansas acted as a catalyst, forcing the United States to finally recognize the sad affairs in Indian Territory and take action.

From a wider perspective, however, the war in Indian Territory adds complexion to the wartime Confederacy. Whites and Indians fought alongside and under one another in an attempt to defend the Confederate borderland. This racial cooperation speaks less to an enlightenment of racial views, but instead to the acknowledgement by both white Southerners and elite Indians that military cooperation would be mutually beneficial. As Chapter One detailed, white Southerners took an interest in Indian politics during the secession crisis of 1861. That interest in Indian affairs continued once hostilities began. Whites wanted to see Confederate Indian Territory defended, if only to protect Arkansas and Texas from Federal incursions. Elite Indians, who saw themselves as part of Southern society, were willing to fight for a place within the Confederacy. Thus, white Southerners and acculturated Indians battled together for the Confederate borderlands throughout much of the war.

The Opothleyahola campaign in particular merits special attention. By all accounts the campaign fails to conform to historians' conceptions of how the war was prosecuted in its infancy. The Confederate 1861 winter offensive targeted Unionists of all stripes, including civilians, and was meant to harass and remove those who failed to acknowledge Confederate authority. The exodus of Opothleyahola's followers remains of one the most heart-rending and relatively unknown chapters of the Civil War. Traveling hundreds of miles in the dead of winter, hounded by Confederate pursuers and bereft of provisions or shelter, thousands of Union Indians trekked north and many died on the march or in the squalor of refugee camps. The "hard-war" 
depicted by historians usually arises in 1863-'64; in the Confederate borderlands, hard-war exhibited itself from the very beginning. By closely examining the Opothleyahola campaign, then, historians gain not only a greater understanding of how the Civil War in Indian Territory developed, but also how war in the far West complicates traditional conceptions of race and war within the Confederacy.

As soon as the Five Tribes joined the Confederacy, war fever swept through the Territory. Regiments were quickly raised for Confederate service, units almost uniformly led by wealthy Indian elites. The same men who had brought the war to the Territory were now to lead them through it. Despite apparent Cherokee unity under the Confederate flag, the rivalry between Chief John Ross and Stand Watie continued. The result was two Cherokee regiments: the $1^{\text {st }}$ Cherokee Mounted Rifles led by John Ross' nephew, and the $2^{\text {nd }}$ Cherokee Mounted Rifles led by Stand Watie himself. The Creeks likewise raised two mounted units for Confederate service, to be headed by brothers Daniel and Chilly of the influential McIntosh clan. The Seminoles coalesced in a battalion around the leadership of their chief, John Jumper. The Choctaws and Chickasaws jointly raised two mounted regiments as well, one led by Tandy Walker and the other by former U.S. Indian agent Douglas Hancock Cooper. ${ }^{49}$

The Five Tribes' treaties with the Confederate States promised that these outfits would be furnished weapons and supplies by the Confederacy. Moreover, Indian troops were protected by treaty from serving outside of Indian Territory; these troops were to be used strictly in defense of their homelands. The promise of weapons, supplies, pay, and staying close to home lured many to the Stars and Bars. By the end of 1861, 5,460 soldiers were serving in Confederate Indian

\footnotetext{
${ }^{49}$ Stephen B. Oates, Confederate Cavalry West of the River (1961, repr., Austin: University of Texas Press, 1994): 18-20.
} 
regiments. Based on the 1860 population of the Territory, excluding slaves, approximately one in ten Indians joined the Confederate army. If it is assumed that roughly half the Territorial population in 1861 was female, a reasonable conjecture tells us that roughly one in five Indian males donned Confederate gray by year's end. ${ }^{50}$

Despite their designations and origins, these regiments were not comprised solely of Native-Americans. White men enlisted alongside their native comrades in Indian units. Hailing from Arkansas and Texas, white neighbors proved willing to cross the border and serve alongside "civilized" Native-Americans. In doing so, they highlighted the continued interest of white neighbors regarding the fate of the borderland.

George Legrand Washington was a 26 year old schoolteacher from Cincinnati, Arkansas, near the Cherokee border, when the Civil War broke out. Hailing from a Southern, slave-holding family, George enlisted in the Cane Hill Rifles, Company D of the Third Arkansas Infantry in July, 1861. Within a month, George and the rest of the Third Arkansas found themselves engaged in "the fiercest and most terrific part" of the Battle of Wilson's Creek in southwest Missouri on August 10. Subjected to artillery bombardment and "exposed to a wasting fire," the Third Arkansas suffered nearly 22\% casualties, including George Washington himself, who was "wounded slightly.",51

${ }^{50}$ It is quite possible that this figure is even higher, since young and old men not of military age would be included in the population total. Oates, Confederate Cavalry West of the River, 29; Doran, "Population Statistics," Chronicles of Oklahoma, 501.

${ }^{51}$ Census records indicate that George Washington's immediate family owned nine slaves in 1860. While George possessed an estimated estate of $\$ 100$, his parents and sister had a combined value of $\$ 5,075$, indicated he came from a family of some wealth. Washington's was one of 109 men wounded with the Third Arkansas at Wilson's Creek, out of 500 men engaged. Adair County Court, State of Oklahoma, "Testimony of Sam Gilbreath", Feb. 21, 1916; Fold3.com (online database), Compiled Service Records of Confederate Soldiers Who Served in Organizations from the State of Arkansas (hereinafter referred to as Compiled Service Records [Arkansas]), Third State Infantry; Ancestry.com (online database), 1860 United States Census, Illinois, Washington County, Arkansas; Ancestry.com, 1860 United States Census-Slave Schedules, Illinois, Washington County, Arkansas; OR, vol. 8, 121, 123-125; Piston and Hatcher III, Wilson's Creek, 335. 
Technically in state, not Confederate, service, the Third Arkansas disbanded not long after the fight at Wilson's Creek. Undeterred, however, George Washington was again in Southern service by 1862 , this time among the Cherokees in Indian Territory. Perhaps drawing upon his teacher's background, George served as a clerk for the $2^{\text {nd }}$ Cherokee Mounted Rifles (Watie's command) for the remainder of the war. ${ }^{52}$

Throughout the war, George Washington discovered a friend in fellow Arkansan schoolteacher Isaac Asbury Clarke, who also served with the Confederate Army in Indian Territory as a clerk. Studying at the University of Missouri in 1861, Clarke penned in January that, "The thought of the proud fabric of the American Government's being destroyed is revolting to true patriotism. I am for the Union. May it yet be preserved.” Although Clarke recognized the possibility of Arkansas' secession, he remained hopeful that "the people they will prove true to the Union." Yet by August Isaac was a quartermaster in the service of the South; he too appears to have gone north to Wilson's Creek, though he likely saw no action. The recommendation of another officer enabled Clarke gain another quartermaster's position with the Confederate Cherokees under Stand Watie; later he would serve in Commissary Department with the $1^{\text {st }}$ Creek Mounted Volunteers. ${ }^{53}$

The "scion of an old and influential Virginia family," William E. Rosser's family suffered financial troubles in 1849, sold their Virginia home and most of their slaves, and started for a new life on a 640 acre farm along the Sabine River in Panola County, Texas. Only three at the time of their arrival, by all accounts William and his siblings enjoyed a true Texan

${ }^{52}$ OR, vol. 3, 715-716; Adair County Court, OK, Testimony of Sam Gilbreath; George L. Washington to David W. Fine, June 29, 1862, George Fine Papers, OHS.

${ }^{53}$ [Isaac A. Clarke?] to P.V., January 5, 1861, Isaac A. Clarke to family, August 3, 1861, Isaac A. Clarke to family, January 26, 1862, and Isaac A. Clark to mother, May 31, 1863, in Wayne Clark, The Letters \& Diaries of Isaac A. Clarke: Innovative Educator in Post-Civil War Arkansas (Victoria, BC: Trafford Publishing, 2006), 4, 23, 25-28. 
upbringing, toiling the fields and keeping an eye out for wild animals. Family tradition holds that one slave was killed by an alligator on the Sabine. ${ }^{54}$

With the outbreak of civil war in 1861, the Rosser children had decisions to make.

William's brother Thomas Lafayette Rosser, as the eldest son, was completing his fourth year at West Point where he had befriended the likes of George Armstrong Custer and John Pelham. William, on the other hand, remained in Texas, just on the cusp of manhood at 17. Both brothers decided to join the Confederate cause, but their paths couldn't have been more different. While Thomas went on to fame and accolades as a Confederate major-general of cavalry in the east under the dashing J.E.B. Stuart, William travelled north to Fort Washita, Indian Territory and enlisted, rather ingloriously, as a corporal in the $1^{\text {st }}$ Choctaw and Chickasaw Mounted Rifles. ${ }^{55}$

It is unknown how many white men in total served in Indian regiments. Company E of the $1^{\text {st }}$ Choctaw and Chickasaw Mounted Rifles was comprised entirely of Texans, who had seized possession of Fort Washita that summer. Other whites, such as Washington, Clarke, and Rosser, simply crossed the border on their own initiative and enlisted alongside their Indian allies. It would be reasonable to assume then, that perhaps several hundred whites served in Indian regiments. ${ }^{56}$

Both wartime Southern leaders and contemporary historians portray a conservative Confederacy built upon the principles white superiority, African-American inferiority, and the preservation of slavery. Confederate Vice-President Alexander Stephens, in his infamous 1861

\footnotetext{
${ }^{54}$ Joseph B. Thoburn, A Standard History of Oklahoma, Vol. 2 (Chicago: American Historical Society, 1916): 1189; Ancestry.com, 1850 United States Census, Panola County, Texas; Millard Kessler and Dean McKoin Bushong, Fightin' Tom Rosser, C.S.A. (Shippensburg, PA: Beidal Printing House, 1983): 1-3.

${ }^{55}$ For more on Thomas L. Rosser's Confederate career, see Millard K. and Dean M. Bushong's Fightin' Tom Rosser, C.S.A. Bushong, Fightin' Tom Rosser, 5-7; Fold3.com, Compiled Service Records of Confederate Soldiers Who Served in Organizations Raised Directly by the Confederate Government (hereinafter referred to as Compiled Service Records [CSA]).

${ }^{56}$ Ed. F. Bates, History and Reminiscences of Denton County (Denton, TX: McNitzky Printing Co., 1918): 256, 349-350; Otis G. Welch to Joseph A. Carroll, May 12, 1861, Portal to Texas History, University of North Texas Libraries.
} 
"Cornerstone" speech, put the matter succinctly: "Our new Government['s]...foundations are laid, it cornerstone rests, upon the great truth that the negro is not equal to the white man; that slavery, subordination to the superior race, is his natural and moral condition." Historians have largely agreed with Stephen's analysis of his own nation and have placed race and white superiority at the forefront of the Confederacy's cause and identity. Charles B. Dew's Apostles of Disunion exposes how Southerners seceded over fears of racial equality, war, and amalgamation. In Confederate Reckoning, Stephanie McCurry highlights how Southern leaders sought to reinforce conceptions of Southern citizenry as white and male. Similarly, William C. Davis casts the Confederacy as an attempt by white, privileged oligarchs to retain control over the South. Slavery has been declared the "central" and "crucial component" of the new Southern nation. In sum, the Confederate States anchored much of its identity in racial terms, emphasizing white superiority over black inferiors. ${ }^{57}$

How then, can we reconcile white Southern men's service alongside and even under their Indian counterparts with white superiority so central to Southern identity? White Confederate service within and alongside Indian regiments testifies to the continued interest of white Southerners in Indian Territory's fate once the war began. Just as whites proved themselves concerned with the secession of the Five Tribes in the summer of 1861, so too were they devoted to ensuring that Indian Territory remained a in the Confederacy's grasp upon the outbreak of hostilities. And ensuring that Indian Territory remained a Confederate borderlands necessitated working alongside the denizens of that place—Native-Americans. White Southerners did not

\footnotetext{
${ }^{57}$ Stephens quoted in Dew, Apostles of Disunion, 14, 77-79; Stephanie McCurry, Confederate Reckoning: Power and Politics in the Civil War South (Cambridge, MA: Harvard University Press, 2010): 23; William C. Davis, Look Away: A History of the Confederate States of America (New York: The Free Press, 2002): 12-13; Drew Gilpin Faust, The Creation of Confederate Nationalism: Ideology and Identity in the Civil War South (Baton Rouge: Louisiana State University Press, 1988): 60; Sarah Anne Rubin, A Shattered Nation: The Rise and Fall of the Confederacy, 1861-1868 (Chapel Hill: University of North Carolina Press, 2005): 3. These works of course represent just a smattering of the works that have emphasized the central role of slavery and race in the formation and identity of the Confederate States of America.
} 
view Native-Americans as racial equals; the often-times condescending or amused way they speak of their native allies testifies to this sense of superiority. Yet Southerners acknowledged the value of Indian warriors to the Confederate cause and could fight alongside them in defending the Confederate borderland. Thus the war created an alliance of necessity between white Southerners of the region, who wanted Indian Territory to remain a Confederate buffer, and acculturated Indians, who saw alliance as a means of continuing to integrate themselves into Southern society.

This wartime racial hierarchy would soon be put to the test. Like other upper South states straddling the border between the Union and the Confederacy, the war came early to Indian Territory. Unlike early confrontations in Virginia and Missouri, however, the threat to Confederate control of Indian Territory came not from invading Yankees, but instead from recalcitrant Indians themselves.

The treaties of alliance forged between the Five Tribes and the Confederacy in the fall of 1861 did not represent the true inclinations of many Indians. Fearful of abolitionism and pushed by the sometimes forceful machinations of their white neighbors, acculturated Indian elites entered into agreements with which significant numbers of traditional Native-Americans disagreed. This disaffection took an immediate form, as well over 4,000 Creeks and Seminoles gathered under the leadership of Creek chieftain Opothleyahola throughout the fall. In communication with Federal authorities in Kansas, hopeful of U.S. assistance, and confident of support among dissident Indians, Opothleyahola firmly rejected Confederate overtures of peace and alliance.

Initially camped in Creek Nation in the heart of the Territory, Opothleyahola's swelling ranks soon stripped the area of forage. With huge herds of cattle, the party moved northwest into 
the fringes of Cherokee land. The Unionist Indians burned the homes of several Confederate sympathizers along the way, and hundreds of local slaves escaped into the relative freedom of Opothleyahola's ranks. Although having given no indication of launching an offensive, Opothleyahola's mere presence in Indian Territory undermined the Confederacy's brand new authority in the region. Recognizing the need to "either compel submission to the authorities...or drive [Opothleyahola] and his party from the country," former U.S. Indian agent and now Confederate Colonel Douglas H. Cooper determined to take the offensive in November, 1861.58

Although Douglas Cooper would of course call upon the Indian troops at his disposal (including the $1^{\text {st }}$ Choctaw and Chickasaw Mounted Rifles which he personally commanded), Cooper also utilized the services of Texan troopers making their way north through Indian Territory in hopes of joining the fray in Missouri. These Texan troopers hailed from the rough young settlements dotting north Texas, places like Sherman, Marshall, and Fort Worth. Ready to fight, they brooked no sympathy towards the enemy's cause. Shortly after the Ninth Texas Cavalry's enlistment, the regimental adjutant was accused of being an abolitionist. While officers debated the adjutant's fate, the boys "en masse took him out and hanged him." Just as Texans had proven forceful in deciding the political allegiance of the Five Tribes, they proved forceful in enforcing allegiance within their ranks as well. And it was these young Texans who splashed across the Red River Indian Territory in 1861 to once again enforce their will on wayward Indians, this time on behalf of the Confederacy. As they moved across the landscape,

${ }^{58}$ Bearss, "The Civil War Comes to Indian Territory," 11-12; "Report of Col. Douglas H. Cooper," January 20, 1862, O.R., vol. 8, 5 . 
these white Southerners got their first real glimpse of Indians, their lifestyles, and their

homelands. The Texans formed mixed impressions of what they encountered. ${ }^{59}$

Private A.W. Sparks' first experience in Indian Territory proved a bright one. Crossing the Red River into Choctaw Nation with the rest of the $9^{\text {th }}$ Texas Cavalry on the last day of October, 1861, the regiment spent their first night in Indian Territory in the small trading town of Boggy Depot. "[A] noted trading point where many trinkets and notions were sold by the Indians," the boys of the Ninth delighted in the Indian goods. "The soldiers of the regiment," Sparks recalled, "bought quite a lot of these gaudy things and on the march next day presented all the colors of the rainbow in fringes, handkerchiefs, shawls, etc."

While Sparks' comrades indulged in the Indian trinkets, still others took more serious stock of the land around them. Private James C. Bates of the Ninth Texas thought the Choctaw Nation "very fine country," and took the trouble to climb to the "most beautiful summit" of a large hill and enjoy “one of the finest views imaginable.” First Sergeant George L. Griscom spent time around Boggy Depot "hunting a great abundance of all Kinds of game." John Douglas Cater, of the $3^{\text {rd }}$ Texas Cavalry, recalled that Indian Territory "was a beautiful country then," dotted with forests, prairies, and "little mountains and valleys." "The Indians," reported

${ }^{59}$ Martha L. Crabb, All Afire to Fight: The Untold Tale of the Civil War's Ninth Texas Cavalry (New York: Post Road Press, 2000): 3-9; George L. Griscom, Fightin' with Ross' Texas Cavalry Brigade, C.S.A.: The Diary of George L. Griscom, Adjutant, $9^{\text {th }}$ Texas Cavalry Regiment, ed. Homer L. Kerr (Hillsboro, TX: Hillsboro Jr. College Press, 1976): 3. The Ninth Texas Cavalry, of whom James Bates and George Griscom were members, was mustered into Confederate service on October 14, 1861 and crossed the Red River north into Indian Territory some two weeks later. Portions of this unit would see action for the entirety of the campaign against Opothleyahola. The Third Texas Cavalry also hailed from north Texas but had been formed earlier in the summer. They had passed through Indian Territory in July and had taken part at the Battle of Wilson's Creek, Missouri in August. The Third Texas would join Confederate forces in Indian Territory later in the campaign against Opothleyhola. Douglas Hale's The Third Texas Cavalry in the Civil War offers an excellent analytical narrative of the Third Texas' experiences; of particular note is the relatively wealthy, slaveholding background from which a disproportionately large segment of the Third Texas hailed.

${ }^{60}$ A.W. Sparks, The War Between the States, As I Saw It: Reminiscent, Historical and Personal (Tyler, Lee \& Burnett, Printers, 1901): 22. 
Cater, "lived in little villages of huts for houses and there were some patches of corn and watermelons. ${ }^{.61}$

As the various Texan regiments marched deeper into Indian Territory, they eventually rendezvoused with their Indian comrades-in-arms. The Ninth Texas was greeted by the "whoops \& yells \& screams" of Indians "painted red with streaks \& spots of black presenting a most hideous appearance." The Indians engaged in "the most extravagant demonstrations of joyfiring guns shouting $\&$ war dancing until nearly morning." The next day brought even greater celebrations, as adjutant George Grissom confided to his diary that "they [the Indians] gave us the real war dance of both nations with which our boys were delighted \& man (self) participated." The Third Texas enjoyed a similar welcome. "Gen. Cooper's Indians received us with a great joy as we march though their camp," A.W. Sparks wrote, "and fired us a grand salute, which we returned with about the same unmilitary regularity." 62

For the first time, Southern soldiers beheld their Indian counterparts. "It was about this time I first saw the regiment of Col. Stanwats [Stand Watie], a fine looking body of men," wrote Private Sparks. "I was told they were of Indian blood, but if they differed from any other regiment in soldier appearance I could not detect it. So different were they from other Indian soldiers that I had met." Colonel Watie's regiment of Cherokees stood apart from Colonel Drew's unit "as they all appeared to be full bloods." James Bates held a decidedly less confident view of his allies. Reflecting upon the unified command of Indian and Texan troops, Bates thought "[t]wo hundred well armed men can rout the whole rabble...I am heartily tired of Indian

${ }^{61}$ James C. Bates, A Texas Cavalry Officer's Civil War: The Diary and Letters of James C. Bates, ed. Richard Lowe (Baton Rouge: Louisiana State University, 1999): 18; George L. Griscom, Fightin' with Ross' Texas Cavalry Brigade, C.S.A.: The Diary of George L. Griscom, Adjutant, $9^{\text {th }}$ Texas Cavalry Regiment, ed. Homer L. Kerr (Hillsboro, TX: Hillsboro Jr. College Press, 1976): 3; John Douglas Cater, As It Was: Reminiscences of a Soldier of the Third Texas Cavalry and the Nineteenth Louisiana Infantry (Austin, TX: State House Press, 1990): 78.

${ }^{62}$ Bates, Texas Cavalry Officer's Civil War, 22; Griscom, Fightin' with Ross' Texas Cavalry, 4; Sparks, War Between the States, 23. 
alliances if all are like [this]." While white Texans' opinions of their Indian comrades may have varied from amusement to admiration to scorn, they nevertheless proved willing to fight alongside Native-Americans. The campaign against Opothleyahola, or "Gouge" as many Texans referred to him, offered the first opportunity for the two groups to fight side by side. ${ }^{63}$

On November $15^{\text {th }}$, a motley column Chickasaws, Choctaws, Creeks, Seminoles and Texans, around 1,400 men in all, set out to hunt down old Gouge under the leadership of Col. Douglas Cooper. Quickly finding Opothleyahola's trail, by the $19^{\text {th }}$ the Confederates had caught up to the old Creek chieftain; the smoke from his campfires dotted the sky. Anxious to close with the enemy, the Ninth Texas Cavalry charged forward with Creeks and Choctaws in support, only to find the camp "recently deserted." Still, the capture of a few prisoners assured the Texans that they enemy lay ahead, and they ploughed onwards "at a furious rate" across three miles of open prairie. ${ }^{64}$

Approaching a belt of timber guarding two round hills, the Texans foolishly "charged \& came into line in fine style." Thinking the enemy was on the run, the Texans instead charged headlong into the main body of Opothleyahola's force of several thousand, which promptly opened fire into the flanks of the Southern troopers. George Griscom recalled that the enemy Indians sent "a pony chased by dogs" through the Texans ranks in an effort to stampede the Rebels' horses. The Ninth Texas found itself in a precarious, and eerie, position. Outnumbered and slowly retreating towards the main Confederate force, the Texans fought in twilight, the flickering flames of prairie fires "in a half a Dozen place affording them light to fight by." 65

\footnotetext{
${ }^{63}$ Sparks, War Between the States, 41-42; Bates, Texas Cavalry Officer's Civil War, 22.

64 "Report of Col. Douglas H. Cooper," January 20, 1862, O.R., vol. 8, 5-6; Griscom, Fighting With Ross' Texas Cavalry, 7.

${ }^{65}$ Ibid.
} 
Relief arrived as the Choctaws and Chickasaws took the field, led by Col. Cooper. The Confederate Indians met their Union counterparts and "a bloody fight of 15 minutes" ensued. The Texans were careful not to again push forward into the fray, as "it was impossible for us to tell even in daylight which of the Indians were our friends and which our enemies." The short, vicious fight among the Indians—-some Confederate, some Union-ultimately resulted in Opothleyahola's forces shrinking back into the darkness. The Battle of Round Mountain, the first major Civil War engagement in Indian Territory, was over. Confederate casualties proved relatively light: six killed, five wounded and missing. Union casualties are unknown; Col. Cooper claimed old Gouge suffered 110 men lost, but this number seems exaggerated. ${ }^{66}$ Although Opothleyahola enjoyed superior numbers and advantageous terrain, it seems likely that Opothleyahola retreated due to his concern for the well-being of the thousands of civilian refugees under his protection. The next day, the Confederates entered the chieftain's abandoned camp and savored the spoils of war. In his desire to quickly escape the enemy's reach, Opothleyahola left behind a dozen wagons loaded with sugar, salt, coffee, flour and other supplies. Oxen, cattle, sheep, over a hundred ponies, and several carriages were all found abandoned by the pursuing Confederates. More darkly, also found were the bodies of two Southern soldiers "taken prisoner by them \& beaten to death.” George Griscom experienced "feeling for the $1^{\text {st }}$ time as one does when leaving comrades slain on the field" and witnessed Confederate "Creeks taking some scalps the $1^{\text {st }}$ I ever saw." Though a small skirmish, the ugliness of war was on full display. ${ }^{67}$

\footnotetext{
66 “Report of Col. Douglas H. Cooper," January 20, 1862, O.R., vol. 8, 5-6; Griscom, Fighting With Ross' Texas Cavalry, 7; Bates, Texas Cavalry Officer's Civil War, 29-30. Bates suggests that 40 or 50 was a more realistic figure regarding the enemy's causalities.

${ }^{67}$ Ibid.
} 
Interestingly silent in Confederate sources is any real discussion regarding for whom all these captured supplies were intended. While it was widely known that Opothleyahola was harboring large numbers of civilian refugees, Confederate commanders and soldiers alike expressed little remorse for driving these hapless civilian further from their homes. The large quantities of food and supplies captured after Round Mountain were just as certainly intended for the needs and wants of women and children as for old Gouge's warriors. By forcing Opothleyahola to abandon his supplies, the Confederate offensive was in turn inflicting suffering upon the civilians Opothleyahola harbored.

The Unionist Indians were given a brief respite from Confederate aggression following the Round Mountain fight when Federal forces in Missouri threatened to invade northern Arkansas. General Cooper's forces were compelled to spend several weeks near the Arkansas border, ready to repel any Federal offensive. When none proved forthcoming, however, Douglas Cooper again renewed his assault on Opothleyahola. Again, Cooper's force was comprised of the $1^{\text {st }}$ Choctaw and Chickasaw Mounted Rifles, the $1^{\text {st }}$ Creek Mounted Rifles, a battalion of Choctaws, and the $9^{\text {th }}$ Texas Cavalry. Also present was a sizable detachment of the $2^{\text {nd }}$ Cherokee Mounted Rifles, an outfit comprised primarily of traditionalist Indians and supporters of John Ross, who were led by Ross' nephew John Drew. Drew's regiment contained more than a few members of the Keetowah Society, whose stance against acculturation and slavery made them uneasy bedfellows with the rest of the Rebel soldiers in Cooper's command. ${ }^{68}$

In early December, Confederate forces again encountered their Union foes on the banks of Bird Creek in Cherokee Nation. Learning that perhaps Opothleyahola possessed "a desire to make peace," Col. Cooper sent a representative to the Creek warrior ensuring that "we did not

\footnotetext{
68 “Report of Col. Douglas H. Cooper," January 20, 1862, O.R., vol. 8, 7; W. Craig Gaines, The Confederate Cherokees: John Drew's Regiment of Mounted Rifles (Baton Rouge: Louisiana State University Press, 1989): 20.
} 
desire the shedding of blood among the Indians" and proposing peace talks be held. The Rebel courier, after his visit to Opothleyahola's camp, returned to Cooper at dusk with stunning news. Contrary to reports, Opothleyahola had no intentions of buckling, and indeed, "his warriors, several thousand in number, were all painted for the fight" and intended to attack that night. There would be no peace among the Indians. ${ }^{69}$

Worse however, John Drew’s regiment of Cherokees, “panic-stricken, had dispersed, leaving their tents standing, and in many instances their horses and guns." Drew's Cherokees had not seen action during the Battle of Round Mountain, so as word spread that another fight with Opothleyahola loomed, many traditionalist Cherokees grappled with the prospect of fighting other traditionalist Indians with whom they empathized. Exacerbating the situation were soldiers who belonged to the Keetowah Society, who were perhaps in contact with Opothleyahola's camp itself. The Keetowahs fanned the flames of panic, warning of an imminent attack and encouraging the traditionalist Indians to defect. Tying cornhusks to their hair, the Keetowahs and others slipped away from Drew's camp and joined their fellow traditionalists alongside Opothleyahola. When the defected Confederate Keetowah met their Union counterparts, they exchanged passwords. "Who are you?" one would ask. "Tahlequahwho are you?" came the response. "I am Keetowah's son," was the final response. Armed with such passwords and devices, Drew's regiment melted away into the night. ${ }^{70}$

John Drew's detachment of the $2^{\text {nd }}$ Cherokee Mounted Rifles had numbered 480 men at the outset of the campaign. By the end of the night only 60 loyal soldiers remained; the rest had

\footnotetext{
69 “Report of Col. Douglas H. Cooper,” January 20, 1862, O.R., vol. 8, 7-8.

70 "Report of Col. Douglas H. Cooper," January 20, 1862, O.R., vol. 8, 7-8; Gaines, Confederates Cherokees, 43-48; "Report of Col. John Drew," December 18, 1861, O.R., vol. 8, 16-18. The chapter "Disgrace at Caving Banks" in W. Craig Gaines' Confederate Cherokees offers an excellent, detailed account of the defection of John Drew's regiment. Even before the defection, Unionist, Keetowah Cherokee had been stirring up trouble among the Confederate full-bloods. Ultimately, some 600 men of Drew's regiment would defect to Opothleyahola's ranks before the campaign ended.
} 
deserted or defected to Opothleyahola's ranks. It marked the only time in the Civil War that a Confederate regiment defected en masse to the Union side. More importantly, however, the defection of John Drew's Cherokees revealed the schism within the Cherokee Nation over secession and the war. With Opothleyahola's band and Drew's defectees, the Cherokee, Creek, and Seminole Nations all had sizable portions of their male populations serving the Union cause. The treaties of alliance with the Confederacy formed just a few months prior were already collapsing; three of the Five Tribes were falling into their own intra-tribal civil wars. ${ }^{71}$

Surely this must have been an unnerving moment for Colonel Cooper. Opothleyahola was coming, and the Cherokees were gone. Luckily for the Cooper, however, reports of Gouge's imminent attack proved false. Still, Cooper now knew that his enemy numbered over 2,000 warriors, and Cooper's command had shrunk by some 400. On the morning of December 9, after spending an anxious night "quietly awaiting the enemy," Cooper began to withdraw his command. Withdrawing in the face of the enemy proved an impossible task, however. Opothleyahola's force assaulted Cooper's rearguard and forced the second battle of the campaign. $^{72}$

The Confederates reacted quickly. Cooper formed his troops into three columns and sent them flying towards the enemy, who were ensconced behind Bird Creek, or Chusto-Talasah as the Indians called it. The Union position was formidable. Opothleyahola's men had taken shelter behind a steep, horseshoe bend in Bird Creek, "densely covered with heavy timber, matted undergrowth, and thickets, and fortified additionally with prostrate logs." Stretching over a mile in length, the center of the enemy's line was anchored by a small house. Opothleyahola

\footnotetext{
${ }^{71}$ Gaines, Confederate Cherokees, 125.

72 “Report of Col. Douglas H. Cooper," January 20, 1862, O.R., vol. 8, 7-8
} 
had proven himself an able commander; while strategically bringing on a general engagement, he had cleverly provided his men with a strong defensive position tactically.

The "rattle of guns and the chatter of the Indians" warned the Confederates of the enemy ahead, and the Rebels were forced to dismount and assault the position on foot. The Creeks, on the Confederate left, attacked first, "charging the enemy with great impetuosity." Shortly after, the Texans and few remaining Cherokees stormed the center of the Union line, and the Choctaws and Chickasaws struck from the Confederate right. James Bates, with the Ninth Texas in the middle of the fray, wrote home that the fight around the house "raged with the greatest fury. Twice we drove them from it and were each time compelled to retire ourselves. The third time however we succeeded in holding it." It was Bates' first engagement, and to his surprise, he found that after "the first few rounds fired-I ceased to have any apprehension whatever of danger." He quickly learned to decipher the sounds different bullets made, and also noted, "An arrow produces a sound something like a bird flying swiftly through the air." ${ }^{, 73}$

Although Opothleyahola's men had been bludgeoned back, they continued to fight on. Accounts differ somewhat on what occurred next. In his official report, Colonel Cooper claimed that as darkness approached, the enemy "disappeared from our entire front" and only after Opothleyahola's retreat did the Confederates withdraw. James Bates thought differently of the matter. Cooper's order to retreat was obeyed with "some reluctance," and Bates felt that with "one more hour of daylight we would have routed them completely." "As it was," Bates penned to his mother, "we were forced to leave the enemy in possession of part of the field and though others think differently I cant call our victory complete." 74

\footnotetext{
${ }^{73}$ Sparks, War Between the States, 43; Bates, Texas Cavalry Officer's Civil War, 44, 46-47.

74 "Report of Col. Douglas H. Cooper," January 20, 1862, O.R., vol. 8, 10; Bates, Texas Cavalry Officer's
} Civil War, 44. 
Once again, the Confederates held a dubious victory at Chustu-Talasah, owing more to Opothleyahola's decision to retreat than any clear battlefield decision. The Confederate forces, numbering 1,100 without Drew's Cherokees, suffered 15 killed and 37 wounded. Opothleyahola's force likely numbered above 2,000. Col. Cooper claimed the enemy's loss to be approximately 500, although such a high figure is almost surely fictitious. Opothleyahola continued his trek northwards, moving ever closer to the relative safety of Kansas. Colonel Cooper, running low on ammunition and recognizing the numerical inferiority of his command, withdrew to Fort Gibson to resupply and regroup. ${ }^{75}$

Despite two sustained efforts, the campaign against the Unionist Indians had not gone well. Many Cherokees had proven themselves Rebels in name only, unwilling to take up arms against their fellow traditionalists and Keetowah brethren. Although still sidling northward, Opothleyahola remained in Cherokee country, a constant symbol of defiance and an embarrassing thorn in the Confederates, and Col. Cooper's, side. Acknowledging his need for additional help, Cooper reached out to Colonel James McIntosh in Arkansas for assistance. Although Cooper already held Texan troops destined for McIntosh's command, the beleaguered Confederate colonel asked for "additional white force" to finally quash Opothleyahola. "The true men among the Cherokees," Cooper warned direly, "must be supported and protected or we shall lose the Indian Territory." Cooper's plea for reinforcements was a tacit admission of his failures thus far. ${ }^{76}$

On December 17, James Bates wrote his brother in law, "Things are rapidly approaching a climax in this section..." The very same day, Col. James McIntosh trotted out of Van Buren, Arkansas with 1,600 Texan and Arkansas horseman to "settle matters in the nation." Arriving at

\footnotetext{
75 “Report of Col. Douglas H. Cooper," January 20, 1862, O.R., vol. 8, 10-11; Bearss, Civil War Comes to Indian Territory, 28-29. The Battle of Chusto-Talasah is also known as the Battle of Bird Creek or Caving Banks.

${ }^{76}$ Douglas H. Cooper to James McIntosh, December 11, 1861, O.R., vol. 8, 709.
} 
Fort Gibson in eastern Cherokee Nation, McIntosh conferred with Cooper and the two planned to entrap Opothleyahola in a wide pincer movement. Riding out of Fort Gibson with 1,380 troopers, McIntosh's force encountered Opothleyahola's warriors along Shoal Creek on December 26. The Union Indians had positioned themselves on a hilltop just beyond the creek, a commanding defensive position. The Seminoles in Opothleyahola's command were headed by chief Halek Tustanuggee, who had spent years in Florida fighting the United States Army in a futile attempt to save his homeland. Decades later and hundreds of miles west, he now cleverly positioned his warriors behind trees to repel the ambitions of the Confederate States. "Each tree on the hill-side screened a stalwart warrior," McIntosh claimed. Beyond the Seminoles atop the crest of the hill were Opothelyahola's Creeks, mounted and ready to sweep away the opposition. Colonel McIntosh, surveying the scene, determined to fight the enemy here, despite the absence of Cooper's men who were miles away. ${ }^{77}$

Unlike Cooper at Chusto-Talasah, McIntosh refused to send his men into battle piecemeal and instead simply ordered a mass charge forward by his entire command. "[T]he order to charge to the top of the hill met a responsive feeling from each gallant heart in the line..." McIntosh effusively reported, "one wild yell from a thousand throats burst upon the air, and the living mass hurled itself upon the foe." The Confederate horseman surged forward, splashing through the cold creek water and soon found themselves at the base of the rocky hill. Pvt. John Cater recalled that, "We formed a line of battle in front of them. Bullets and arrows were coming pretty fast. A feathered arrow passed in front of my face just before we were ordered to dismount, and produced a strange sensation in me." The Southerners pushed up the hill on foot, and the Seminoles fell back into Opothleyahola's mounted men, producing

\footnotetext{
${ }^{77}$ Bates, Texas Cavalry Officer's Civil War, 53; James McIntosh to S. Cooper, December 16, 1861, O.R., vol. 8, 715; "Report of Col. James McIntosh," January 1, 1862, O.R., vol. 8, 22-25.
} 
confusion. For a brief moment, the two sides collided at the summit of the hill, at times Indians and Southerners grappling in hand-to-hand combat. Then the Union Indians went tumbling back, retreating into "the rocky gorges and deep recesses of the mountains" behind them. The Confederate troops, instead of immediately pursuing, went back to their horses, remounted, and then took off in pursuit of their fleeing foe. "Some of those fellows," John Cater admitted, "were very brave and daring and would not leave, but continued to shoot.” A last stand by Opothleyahola's men at their encampment failed, and the Unionist Indians finally routed and scattered in all directions. Under the direction of James McIntosh, the Confederates at the Battle of Chustenahlah accomplished what Douglas Cooper could not; Opothleyahola and the Union Indians had been decisively defeated. The Confederates suffered 9 killed and 40 wounded; the Confederates placed their usually bloated figure of the enemy's casualties at $250 .^{78}$

As the Confederate regrouped, they took stock of what they had captured. As at Round Mountain, the loot at Chustenahlah included 30 wagons, 70 oxen, 500 ponies, hundreds of cattle, sheep, and plenty of provisions and property. Unlike previous engagements, however, the Confederates were now responsible for hundreds of captured Indians themselves, a testament to how disastrous the Confederate breakthrough had been for the Union forces. At least 160 women and children, 20 blacks, and one wounded warrior were captured by the Confederate forces. $^{79}$

Over the next several days, the chase after Opothleyahola's retreating party continued. McIntosh's men were joined the pursuit by Col. Cooper's mixed force of Indians and Texans and Colonel Stand Watie's $2^{\text {nd }}$ Cherokee Mounted Rifles. Although unable to capture

\footnotetext{
78 “Report of Col. James McIntosh,” January 1, 1862, O.R., vol. 8, 22-25; Cater, “As It Was,” 103-104. John Cater offers a much higher figure of 300 civilians captured. Cater also informs us that the captured blacks were taken to Fort Smith, where a return to slavery most likely awaited them.

${ }^{79}$ Ibid.
} 
Opothleyahola's main body, by nipping at the heels of Gouge's force and constant skirmishing, close to one hundred more prisoners were captured, hundreds of cattle taken, a pair of wagons burned, and several more warriors killed and wounded. Finally satisfied that Opothleyahola had been permanently driven from the Territory into Kansas, the hunt was called off.

From a military perspective, the late 1861 campaign against Opothleyahola was a relatively minor affair. A series of three skirmishes, the campaign drove the wayward Creek chieftain from Confederate Indian Territory into an unhappy Kansan exile. The number of troops engaged was relatively small and the military casualties light. The Confederates secured land of limited strategic importance, and inflicted no real injury on any Federal force or the broader Union war effort.

Yet from a political perspective, the campaign was a Confederate nightmare that actually exacerbated the problems it was meant to remedy. In driving Opothleyahola out of the Territory, Colonel Cooper meant to solidify the Confederacy's hold over the Five Tribes. Instead, the campaign fractured the Cherokee Nation along already shaky fault lines, causing hundreds of sympathetic traditionalist Indians to desert the Confederate cause and take up arms against the South. Now three of the tribes-Creeks, Seminoles, and Cherokees - were embroiled in their own internal civil wars. The failure of Cooper to defeat Opothleyahola at Round Mountain and Chusta-Talasah embarrassed the commander and the Confederacy, and it was only with the outside help of James McIntosh and his white troops that Gouge was finally defeated.

While Confederates enjoyed their triumph, the sting of defeat for Opothleyahola's followers was only the beginning of their sad saga. Unfortunately, few contemporary records exist detailing their journey north into Kansas, but close reading of Confederate sources and post-war interviews do provide some insight into their struggles. Although a reasonable estimate 
of Opothleyahola's force approximates 5,000, it is unclear just how many made the final journey north to Kansas following the disaster at Chustenahlah. Colonel McIntosh thought old Gouge took "not more than 400 to 500 Creeks with him." It is unclear whether McIntosh is referencing the number of warriors who fled north, or Opothleyahola's entire party. Considering the thousands of Creeks, Seminoles, defected Cherokees, and runaway slaves with Opothleyahola, and the Confederate's capture of only several hundred Unionists, it seems likely that several thousand Unionists ultimately made the trek. Documents from late January, 1862 indicate that nearly 6,000 Indians had taken shelter in Kansas. While Chustenahlah dispersed the Unionist Indians, and perhaps persuaded some to come into the Confederate fold, it appears that most Unionist Indians stayed true to their sentiments and accepted a Kansan exile. ${ }^{80}$

The journey north into Kansas by Opothleyahola's followers is one of the most heartbreaking, and relatively unknown, chapters of the Civil War. An exodus of immense suffering and fear, thousands of refugees were pushed from their homes to camps on the cold plains of Kansas. The Confederate pursuit of the Unionist Indians forced Gouge's followers to both fend off Confederate attacks on their rear guard and push on at a quick pace. Jackman Pidgeon remembered the stories his mother Smaddie told of their unhappy journey north. "There were times, as she told," Pidgeon related, "when they were overtaken by their pursuers, those serving with the Confederates," but Opothleyahola's sheer numbers allowed his followers to fend off their attackers. At one point, Smaddie Pidgeon's party was overtaken by the Confederates, and Unionist warriors were forced to "check the rear attackers." Smaddie watched the fight unfold from a hilltop. "At dark, as the firing kept on, the scene... seemed to be like the flicker of fireflies, with reports of guns heard and flashes here and there of the shooting." These

\footnotetext{
80 "Report of Col. James McIntosh," January 10, 1862, O.R., vol. 8, 31; Hopoeithleyhohola [Opothleyahola] and Aluksustenuke to Abraham Lincoln, January 28, 1862, O.R. vol. 8, 534.
} 
attacks cause the greatest panic. James Scott, ten years old at the time, witnessed one such heartrending scene during a Confederate assault. "One time we saw a little baby on its blanket in the woods. Everyone was running because at attack was expected and no one had the time to stop and pick up the child. As it saw the people running by, the little child began to wave its little hands. The child had no knowledge that he had been deserted."

These constant attacks, beyond exciting panic, fear, and suffering, also meant that wagons, cattle, and other much needed supplies often had to be abandoned in order to escape. James Scott recalled years later, "We faced many hardships, we were often without food, the children cried from weariness and the cold, we fled and left our wagons with much needed provisions, clothing and other necessities... When our provisions went low, some of the members of the tribe turned to eating horse flesh., ${ }^{82}$

Other memories suggest incredible acts of brutality took place. "Some women carrying children would be overtaken by Confederate soldiers and the soldiers snatched the children from the arms of the mothers and smashed their heads against the trees." It cannot be stated for sure whether or not such horrific incidents occurred; time and hand-me-down tales can warp any story. Yet considering the reports of scalping and murder by Southern Indians during the campaign, it's not implausible that the sad tale was relayed correctly. Missionary Stephen Foreman, writing in his diary on January 3,1862, relayed news given to him by soldier returning from the campaign. "They are just from Opothleyahotah's [sic] camp, whither they went to give him, as they said a brushing," Foreman notes. "It is estimated that they killed about two hundred

\footnotetext{
${ }^{81}$ Interview with Jackman Pidgeon, February 21, 1938, Indian Pioneer Papers, WHC, University of Oklahoma; Interview with James Scott, March 29, 1937, Indian Pioneer Papers, WHC, University of Oklahoma.

${ }^{82}$ Interview with James Scott, March 29, 1937, Indian Pioneer Papers, WHC, University of Oklahoma.
} 
prisoners, including some women and children." Again, whether such wholesale slaughter occurred is unclear. But the evidence does suggest that the campaign was a dirty one indeed. ${ }^{83}$

The environment proved almost as vicious a foe as the Rebel pursuers. Many Confederate accounts of the period reference the bitter cold and lack of forage. James Bates wrote of taking walks to keep warm in the night. "Cold enough to freeze my breath on my mustache," he complained in his diary. In chasing Opothleyahola, Bates also took note of the "very rugged country" through which they passed. George Griscom agreed. "Very rough Broken country" his brief diary entry admits. Even James McIntosh notes in his official report that the Confederates, and hence also Opothleyahola's sad band, marched "on ground covered with snow and at other times facing the chilly blasts from the north." Lindy Scott was told stories of how "The leg, arm, toes or fingers of some of the Indians were lost by being frozen and they would have to be amputated in the best manner possible." The lack of clothing showed, too, as "Many of the Indians [went] barefooted in the sleet and snow." 84

Arrival along the Verdigris River basin in Kansas offered shelter from the Confederates but not from the elements. Poor, handmade tents—-stitched together with rags, handkerchiefs, anything — offered little protection from the snow and wind. When an army surgeon visited in February, he found seven children stark naked. Two thousand ponies died in the Kansas camps from the cold, and poor sanitation made the water "unfit for use." The refugees continued to

${ }^{83}$ Interview with James Scott, March 29, 1937, Indian Pioneer Papers, WHC, University of Oklahoma; Stephen Foreman Papers, diary entry January 3, 1862, WHC, University of Oklahoma.

${ }^{84}$ Bates, Texas Cavalry Officer's Civil War, 61-62. Griscom, Fighting with Ross' Texas Cavalry Brigade, 11; "Report of James McIntosh," January 1, 1862, O.R., vol. 8, 24; Interview of Lindy Scott, October 29, 1937, Indian Pioneer Papers, WHC, University of Oklahoma. 
suffer until their eventual removal to the land around LeRoy, Kansas, and the arrival of supplies from the United States. ${ }^{85}$

Thousands of Creeks, Seminoles, Cherokees, runaway slaves, men, women, children, and elderly made the three hundred mile exodus from Indian Territory to the Verdigris River in Kansas. Hounded by Rebel pursuers, whipped by the wind and cold, bereft of provisions or property, the journey exacted an unknown price, although surely many died along the way. United States Indian Agent George Cutler, reflecting upon the refugee's journey, stated simply, "I doubt much if history records an instance of sufferings equal to these."

The campaign against Opothleyahola revealed how the war in the borderlands would be fought. Mounted, mobile military forces engaged one another in small battles that inevitably embroiled the local civilian population into war's suffering. It is no mistake that almost every Indian regiment raised in 1861 for the Confederacy was mounted, nor that the majority of white units that fought in the Territory were also mounted. This preference for going to war on horse was prevalent throughout the Trans-Mississippi theater, where one hundred sixty-one mounted units were raised for Confederate service during the war. As Stephen B. Oates argues in Confederate Cavalry West of the River, the use of mobile troops proved exceedingly useful in chasing down wily Opothleyahola and exhibited "the tremendous striking power" of cavalry. Considering the vast spaces and comparatively small populations of Trans-Mississippi states, cavalry created a much needed mobility for commands that needed to protect long, vulnerable frontiers. $^{87}$

${ }^{85}$ Debo, The Road to Disappearance, 151; George A. Cutler to William G. Coffin, September 30, 1862, Report of the Commissioner of Indian Affairs for the Year 1862 (Washington: Government Printing Office, 1863): 139.

${ }^{86}$ George A. Cutler to William G. Coffin, September 30, 1862, Report of the Commissioner of Indian Affairs for the Year 1862 (Washington: Government Printing Office, 1863): 139.

${ }^{87}$ Oates, Confederate Cavalry West of the River, xv, 33. 
Historians have long-offered a declensionist narrative regarding violence, brutality, and civilian suffering in the Civil War, whether from top-down official policy to soldier's view of the conflict. Mark Grimsley's Hard Hand of War details how Union military policy evolved from a conservative, conciliatory approach to a policy of "hard war," meant to "demoralize Southern civilians and ruin the Confederate economy." Gerald F. Linderman's Embattled Courage also depicts a war that grew increasingly harsh overtime, highlighting 1864 as the tipping point for "warfare of terror" that was waged against Southern civilians. Charles Royster utilizes “Stonewall” Jackson and William Tecumseh Sherman as mediums through which an increasingly violent, aggressive war was persecuted. All of these works depict a war that grew mean over time, where civilians were slowly but inexorably pulled into and targeted by the conflict around them. ${ }^{88}$

The campaign against Opothleyahola stands at odds with this declensionist understanding of the war. On the Confederate borderlands, in the first year of the war when most of North and South lay untouched, an organized, mixed-race Southern military force battled a largely unaggressive foe whose number consisted largely of civilians. In launching an offensive against Opothleyahola, Confederate soldiers were deliberately seeking to punish and expel both soldiers and civilians who disagreed with their vision of a Confederate Indian Territory. They sought to demoralize Unionists, exorcise them from their homes, and force them to submit to Confederate authority or leave.

${ }^{88}$ Mark Grimsley, Hard Hand of War (New York: Cambridge University Press, 1995): 3; Gerald F. Linderman, Embattled Courage: The Experience of Combat in the American Civil War (New York: The Free Press, 1987): 180; Charles Royster, The Destructive War: William Tecumseh Sherman, Stonewall Jackson (New York: Alfred A. Knopf, 1991): xi, 35, 79. Interestingly, Mark Grimsley notes that the conciliatory policy never took deep root in the Western and Trans-Mississippi theaters of war, noting that a harder war was executed earlier there than in the east where a conservative war policy took much deeper root. Grimsley's "hard war" is one generally focused on undercutting Southern morale by the destruction of property; to an extent, the conflict we see in Indian Territory exceeds Grimsley's definition since civilians themselves are often times the victims of violence. For lack of a better term, however, I have appropriated Grimsley's term and argue that a variant of the hard war existed on the Confederate borderland. 
It would be too coy to suggest that this offensive stemmed from any official war policy; it did not. It is more than likely that Confederate authorities in Richmond and perhaps even Little Rock little understood just what the expulsion of Opothleyahola would entail. A disconnect between Confederate high command and Confederate colonels on the ground allowed such a brutal undertaking to go forward. Yet the absence of any real description of civilian suffering in Confederate sources remains striking. As McIntosh's, Cooper's, and Watie's troopers hunted down parties of Unionist Indians and captured hundreds of women and children, they saw firsthand the suffering and devastation they inflicted on their foe. Blood on ice from bare-feet, frostbitten limbs, abandoned children, perhaps even brutal murder would all have been visible. The silence in Southern sources suggests that these Confederates were too uncomfortable to record what they had seen or had no qualms about the ugliness of the conflict in which they were engaged. Perhaps, too, the refugees' race also allowed Southerners to persecute a campaign against civilians. Although willing to serve alongside Confederate Indians, often of a more genteel, elite background, white Confederates in particular may have taken solace that they were hunting down traditionalist, uncivilized, and disloyal Indians. One wonders if such a campaign would ever have been mounted against a Unionist camp of white refugees?

This campaign does not overturn the wider narrative of scholars who depict a war that grew hard over time. But it complicates that narrative, adding an outlier for which historians must account. It suggests that the war in the Confederate borderland was hard from the beginning, civilians were in danger from the beginning, complicated race relations shaped the conflict, and that Confederate control over Indian Territory was tenuous at best. 


\section{Chapter Three: The Federal Indian Expedition}

The frontier sky illuminated an eclectic column of troops moving through Indian

Territory. Whites and Indians marched together, the Indians singing lustily, "in good stile and in fine spirits [sic]." Their uniforms were ill-fitting; the "new uniforms and small Military caps on their Hugh Heads of Hair made rather a Comecal Ludecrous appearance [sic]." Still, the Indians had every reason to be happy. They were coming home. The uniforms they wore were blue, not gray, and they marched to liberate their homelands. It was June, 1862, and the Federal army had finally arrived in Indian Territory. ${ }^{89}$

With the arrival of Federal forces in Indian Territory in the summer of 1862, the scope of conflict in Indian Territory mushroomed in size. Many Indians rushed to the Union cause, and intra-tribal civil wars ripped apart the landscape for three more years. Two narratives emerge from the war waged in Indian Territory. First, the First Indian Expedition projected Union power into the heart of the Cherokee and Creek Nations. Militarily, the war in the Confederate borderlands differed from the war in the East. Relatively few military engagements of significant size took place, although those that did proved quite significant in shaping events. Instead, the war in Indian Territory consisted of an endless series of skirmishes, raids, and guerrilla actions. This brutal type of conflict better mirrors the conflict in places like southern Missouri, northern Arkansas, and eastern Tennessee than the great campaigns in Virginia and Pennsylvania. Moreover, both Northern and Southern whites, Indians from a variety of tribes, and African-Americans all participated in this borderlands bloodletting.

Second, as often occurs in guerrilla wars, the lines between legitimate military actions and banditry blurred, with civilians often suffering at the hands of enemies whose allegiance to 123 , n. 309.

${ }^{89}$ William G. Coffin to Dole, June 25, 1862, quoted in Abel, American Indian in the Civil War, 1862-1865, 
any real cause other than their own was questionable. For Native Americans who attempted to ride out the war years in their homes, desolation and suffering was often their reward. Many Native-Americans, in an attempt to preserve their lives and property, instead sought refuge around garrisoned military posts or in the border communities of Kansas and north Texas.

The exodus of Opothleyahola's followers in late 1861 had driven Unionist presence from Indian Territory. Yet Confederate leaders had failed to take into account the long-term ramifications of their actions. Besides splintering the Cherokee Nation, they had also sent thousands of forlorn Indian refugees into exile in Union Kansas. It did not take long for these Union Indians to begin clamoring for a return to their homes, and for the United States government to finally address the unhappy situation in Indian Territory. In short, by defeating Opothleyahola and sending him north, the Confederacy was providing the impetus for a Federal invasion, a far greater challenge than Opothleyahola alone ever posed.

Kansas strained under the refugees pouring across its borders. Over 13,000 refugees, mostly Indians, huddled in camps along the Verdigris and Neosho Rivers. This figure does not include the thousands of black slaves from Missouri, Indian Territory, and even Texas who sought Kansas in search of freedom. These refugees wanted to go home, and more than a few expressed a willingness to do so in a blue uniform. Almost from their arrival, informal plans were underway by local Federal authorities to utilize this source of manpower. In the winter of 1861-'62, General David Hunter and tribal leaders among the refugees “agreed, that two Regiments should be raised of loyal Indians." Their express purpose would be to "act as Home Guards, who, with a military force of white men to accompany them, would move into the Indian 
Territory, to expel the Rebel Forces and hold the country." Such an expedition would then allow the refugees to "be taken home." 90

By February, enlistments were underway. The First Indian Home Guard consisted of eight companies of Creeks and two companies of Seminoles; many of these recruits had travelled north with Opothleyahola. The Second Indian Home Guard consisted of members of all Five Tribes. By June, some 1,600 Indians, along with a number of runaway black slaves and a smattering of whites, had enlisted in the two regiments. The newly-minted Federal soldiers were "anxious to learn and full fight."

While the United States began to marshal the thousands of Unionist Indians spilling into Kansas, the Confederate Indians were serving their nation outside of the Territory's borders. In January, 1862, Confederate President Jefferson Davis appointed General Earl Van Dorn head of the Military District of the Trans-Mississippi, and the impetuous Van Dorn had high ambitions for his post. He hoped to drive the Federal army out of northern Arkansas and reclaim Missouri for the South—a long-held Confederate dream. Gen. Van Dorn marshaled a force of some twenty thousand Confederate Arkansas, Texans, and Louisianans to drive back the Yankee foe. Also included in this force were 2,500 Confederate Indians under General Albert Pike, including Stand Watie's and John Drew's (reconstituted) First and Second Cherokee, Douglas Cooper's $1^{\text {st }}$ Choctaw and Chickasaw, and Daniel McIntosh's $1^{\text {st }}$ Creek regiments. ${ }^{92}$

According to their treaties with the Confederacy, the Five Tribes' Indian regiments did not have to serve outside of the Territory's borders. General Van Dorn, however, ignored the

\footnotetext{
${ }^{90}$ Mark A. Lause, Race and Radicalism in the Union Army (Springfield: University of Illinois Press, 2009): 61; James G. Blunt to Caleb B. Smith, November 21, 1862, Abraham Lincoln Papers, American Memory Project, Library of Congress.

${ }^{91}$ Lause, Race and Radicalism in the Union Army, 64; Confer, The Cherokee Nation in the Civil War, 7475; William Weer to Thomas Moonlight, June 18, 1862, O.R., vol. 13, 434.

${ }_{92}$ William L. Shea and Earl J. Hess, Pea Ridge: Civil War Campaign in the West (Chapel Hill: University of North Carolina Press, 1992): 20-25, 336.
} 
treaties' stipulations and ordered the Indian troops to assist his forthcoming campaign. Angry over the treaty violation, many Indians refused to march east into Arkansas. Ultimately only the First and Second Cherokee would see battle. Had Van Dorn known what the outcome of their presence would be, he may have simply left the Indian troops in their Territorial homelands. ${ }^{93}$

On March 7, 1862 at the Battle of Pea Ridge in northwest Arkansas, the twin Cherokee regiments under Cols. Watie and Drew squared off against two companies of Iowa cavalry and a Missouri artillery battery. Alongside their Texan comrades, the Cherokees advanced both mounted and on foot and sent the outnumbered Iowan cavalry flying. Capturing the Missouri artillery, Confederate cavalrymen — white and Indian alike—conglomerated around the captured guns, excited by the successful charge and preoccupied with the scene around them. "The Indians," remembered one Southerner, "swarmed around the guns like bees, in great confusion, jabbering and yelling at a furious rate." Excited by battle and without orders, the situation quickly grew out of a hand. ${ }^{94}$

Although the exact details of what happened next are hazy, it is clear that at least some of the Cherokees killed wounded Iowans and scalped at least eight bodies. After the battle, an adjutant of the Third Iowa Cavalry reported, "I also saw bodies of the same men [the 8 men scalped] which had been wounded in parts not vital by bullets, and also pierced through the heart and neck with knives," evidence that "fully satisfied" the adjutant that his fellow Iowans had been "brutally murdered." Whatever brutality occurred, it ended when Federal artillery arrived on the field and sent the Indians "hurriedly" retreating. ${ }^{95}$

\footnotetext{
93 Ibid, 25, 58.

94 Shea and Hess, Pea Ridge, 101-103; James Harding, quoted in Shea and Hess, Pea Ridge, 102.

${ }^{95}$ Shea and Hess, Pea Ridge, 102; John W. Noble to Samuel R. Curtis, April 12, 1862, O.R., vol. 8, 207; "Report of Brig. Gen. Albert Pike," March 14, 1862, O.R., vol. 8, 288. For a good overall view of the Indian's participation in the campaign, also see Roy A. Clifford, "The Indian Regiments in the Battle of Pea Ridge," Chronicles of Oklahoma, vol. 25, no. 4, 214-322. For a concise general overview of the Pea Ridge campaign, see William L. Shea, War in the West: Pea Ridge and Prairie Grove, Civil War Campaigns and Commanders Series
} 
The incident at Pea Ridge sparked a testy exchange between the Union and Confederate army commanders following the battle, which ended in Confederate defeat. The Union army commander sent Gen. Van Dorn a terse message conveying his "regrets that we find on the battlefield, contrary to civilized warfare, many of the Federal dead who were tomahawked, scalped, and their bodies shamefully mangled." The Union general expressed his hope the war would not "degenerate to a savage warfare." Confederate Gen. Van Dorn responded with an accusation of his own. While Van Dorn noted that his Indian forces had for many years "been regarded as civilized people," he too wanted to repress "the horrors of this unnatural war." Van Dorn then went on to claim that Confederate prisoners had been murdered "in cold blood by their captors, who were alleged to be Germans." 96

While Cherokee soldiers did scalp and kill wounded at Pea Ridge, it is telling that the incident has grown in the legend and myth surrounding the battle. It is unsurprising that the Cherokees acted as they did. Just several months before the Cherokees had participated in a campaign where scalps were taken, prisoners beaten, and women and children driven destitute along the frigid plains. In short, scalping and the killing of prisoners were hallmarks of the western war that raged along the Confederate borderlands. The abuses of Pea Ridge were not the first atrocities to happen, nor would they be the last. Yet because they happened to white soldiers on a prominent battlefield, outrage ensued. It is ironic that while Union General Samuel Curtis accused the Confederates of utilizing "savage" warfare via Indians, Union General David Hunter was busy recruiting members of the same tribes for the Indian Home Guard a few

(Fort Worth: Ryan Place Publishers, 1996); for a detailed, thorough campaign study, look to Shea and Hess' Pea Ridge: Civil War Campaign in the West.

${ }^{96}$ T.I. McKinney to Earl Van Dorn, March 9, 1862, O.R., vol. 8, 194; Dabney H. Maury to Samuel R. Curtis, March 14, 1862, O.R., vol. 8, 195. Van Dorn's accusation of German atrocities, probably trumped up, fits well into a larger trend of Germans being victims of nativism during the Civil War. Most notably, the heavily German $11^{\text {th }}$ Corps of the Army of the Potomac often served as a scapegoat for Union blunders; see Christian B. Keller, Chancellorsville and the Germans: Nativism, Ethnicity, and Civil War Memory (New York: Fordham University Press, 2007). 
hundred miles away. Enemy Indians were often "savage," while friendly Indians were usually “civilized."

Following the defeat at Pea Ridge, the Confederate Indians returned home. General Pike stationed them in Choctaw Nation in southern Indian Territory, hardly a place to stymy a Federal invasion from Kansas. And an invasion was surely coming. Colonel William Weer, a Kansan jayhawker and one known to imbibe, assembled an invasion force throughout the summer of 1862. Under Weer's direction, on June 28 the First Indian Expedition was underway as nearly 6,000 Ohioans, Indianans, Wisconsinites, Kansans, and Indians marched south together to retake Indian Territory for the Union. ${ }^{97}$

In some respects, the campaign was a disaster. The bulk of the enemy's forces were far to the south in Choctaw Nation; only Stand Watie's Cherokees offered limited resistance. Small skirmishes in early July at Spavinaw Creek and Locust Grove, Cherokee Nation helped boost Union morale and drive Watie southward, but no decisive fight occurred. The expedition, with no enemy to fight and no clear objective, listlessly continued southward. Meanwhile, the supply line back to Fort Scott, Kansas, grew longer and longer.

Logistical problems and general incompetence plagued the whole operation. As the expedition moved south, food and supplies grew scarce, and supplies from Kansas failed to arrive. Advancing over one hundred miles into Indian Territory, the lack of water grew serious. All that was available was "putrid, stinking water." Luman Tenney, a trooper of the Second Ohio Cavalry, wrote home, "The greatest trouble so far has been the scarcity of water...I feared there would be a mutiny that day, so many boys hadn't had water and weren't permitted to leave the ranks to get any." Compounding the problem was the "violent southern sun," which

${ }^{97}$ William Weer to Thomas Moonlight, June 22, 1862, O.R., vol. 13, 443-44; F. Salomon to William Weer, June 30, 1862, O.R., vol. 13, 458; Confer, Cherokee Nation in the Civil War, 76-77. 
according to Tenney's thermometer hit temperatures "as high as one hundred and twelve in the shade. $" 98$

Discipline and intoxication were problems, too. On the Fourth of July, Luman Tenney penned sarcastically, "Great day. So many drunk. Officers gave the freest license to the men. Both caroused. I was most disgusted." In a letter home, he confided that "One officer even told his men that the one who wasn't drunk that night should be ducked in the Grand River...Col. Weir, our commander, was so intoxicated that he could neither receive the report of battle or give any orders." On July $9^{\text {th }}$, Tenney complained, "March all the forenoon, and went only five miles forward. So many blunders." The general incompetence of many officers, but especially the expedition's commander William Weer, ensured the little was done to rectify the water scarcity, the need for provisions, or the lack of communication from Kansas. ${ }^{99}$

On July 17, Colonel Weer ordered a council of war, which "decided that our only safety lay in falling back to some point from which we could reopen communications with our commissary depot." Col. Weer ignored the council's decision, and the next day he was arrested by the expedition's second-in-command Frederick Salomon, who promptly ordered the expedition to begin retreating north. In his diary, Luman Tenney wrote of the arrest, "I never saw so much excitement. All were glad." Col. Salomon left the First and Second Indian Home Guards to occupy that portion of the Cherokee Nation north of the Arkansas River. The First Indian Expedition, a three week affair, was over. ${ }^{100}$

\footnotetext{
${ }^{98}$ Frederick Salomon, July 18, 1862, O.R., vol. 13, 475-76; Luman Harris Tenney, The War Diary of Luman Harris Tenney, 1861-1865 (Cleveland, OH: Evangelical Publishing House, 1914): 20-21.

${ }^{99}$ Tenney, War Diary, 20-21.

${ }^{100}$ Frederick Salomon, July 18, 1862, O.R., vol. 13, 476; Tenney, War Diary, 21; Lause, Race and Radicalism, 72. Colonel Salomon most certainly took his career in his hands by arresting Colonel Weer. If not vindicated, Salomon could have been charged with mutiny. Salomon's superior, however, James G. Blunt supported the Wisconsin colonel's actions, although Blunt was furious that most of the expedition was pulled back to Fort Scott, Kansas causing "the abandonment of the Indian country." It is worth noting that Col. Salomon's brother was the governor of Wisconsin.
} 
Parched, hungry soldiers and William Weer's career were, in reality, the least-harmed victims of the Indian expedition. The expedition had been undertaken primarily to ease the suffering of Indian refugees in Kansas and allow them to return home. Many had followed the Union expedition southwards, only to watch most of the Union soldiers turn around and march back north. Thousands more were preparing to return to the Territory, only to be advised to stay in their refugee camps in Kansas. As many as 3,000 Indians accompanied the Union soldiers who trudged back north in July; instead of alleviating the refugee situation, the failed expedition aggravated it, adding to the total number of refugees in Kansas. Moreover, desertion among the Indian Home Guard regiments skyrocketed as the U.S. army failed to liberate their homelands. ${ }^{101}$ Although the expedition failed in its mission to retake Indian Territory and allow the refugees to return home, the sudden presence of Union soldiers among the Five Tribes in the summer of 1862 (their first appearance since withdrawing from the Territory in May, 1861) did provide some important secondary accomplishments. A strong, if brief, Union military presence induced many Cherokees to enlist in the Union ranks. Once again, John Drew's regiment of Confederate Cherokees, painstaking rebuilt after the Opothleyahola campaign, defected to the Union side, nearly 600 men total. These defected Confederates formed the nucleus of the newly formed Third Indian Home Guard regiment. ${ }^{102}$

The most important defection to the Union cause, however, was no everyday Cherokee warrior. From the expedition's outset, Union leaders had hoped to sway Cherokee Chief John Ross to the Union cause. "John Ross is undoubtedly with us, and will come out openly when we reach there," wrote Col. William Weer before the expedition began. "I am in receipt of information that large bodies of Union Indians exist among all these people clear to Fort Cobb,

\footnotetext{
${ }^{101}$ James G. Blunt to Caleb Smith, November 21, 1862, Abraham Lincoln Papers, American Memory Project, Library of Congress; Lause, Race and Radicalism, 73-74.

${ }^{102}$ Lause, Race and Radicalism, 70; Gaines, Confederate Cherokees, 110-112.
} 
and that they await our advance in order to take the field in behalf of the government." On June 26, Weer communicated to Ross that his expedition would provide Ross and other Unionists with "an opportunity to show their loyalty to the United States Government.",103

On July 7, Cherokee and pro-Confederate missionary Stephen Foreman paid a visit to Chief John Ross to ascertain "if he should receive propositions from the Northern Government to come under the old Treaties." Ross apparently responded, "I do not know-one thing is clear, we should have to submit to superior power." The missionary was neither impressed nor surprised by Ross' answer, for Foreman suspected Ross of "trying to be a northern and southern man both at the same time." Stephen Foreman's suspicions were soon validated. ${ }^{104}$

Just over a week later on July 15, Chief John Ross was arrested by Union forces, immediately paroled, and accompanied Union forces away from his home in Park Hill. His arrest saved him the embarrassment of betraying his treaty with the Confederacy. It was clear to all, however, that John Ross and his followers (including Drew's warriors) had abandoned a Confederate cause they never placed much faith in and had defected to the Union side. John Ross would spend the rest of the war in exile in Philadelphia. His followers, now allied with the Union, would continue to fight the war in Indian Territory. ${ }^{105}$

The First Indian Expedition, weighed on the whole, represented a tremendous failure with an equally tremendous silver-lining. The expedition failed to secure Indian Territory, particularly the Cherokee and Creek Nations, for the Union. This failure resulted in many refugees traveling southward needlessly, and ultimately thousands more Indian refugees pouring

${ }^{103}$ William Weer to Thomas Moonlight, June 13, 1862, O.R., vol. 13, 430; James A Phillips to John Ross, June 26, 1862, O.R., vol. 13, 1862.

${ }^{104}$ Stephen Foreman Papers, WHC, University of Oklahoma.

105 Gaines, Confederate Cherokees, 108-109; 115. 
into Kansas. The Unionist Indians could not yet safely return home; those who did risked the suffering that comes with a wartime no-man's-land.

Yet the expedition, the first real show of Union military force, made permanent the schism within the Cherokee Nation. From the very outset of the war, it was clear that a Confederate alliance was never the desire of Chief John Ross or his followers. It was Ross' followers, many of whom were Keetowah, who packed the ranks of John Drew's Cherokee regiment. It was Ross' followers who subsequently abandoned the Confederacy and joined with Opothleyahola at the Battle of Chusto-Talasah. It was Ross' followers who again defected, this time permanently, to the Union expedition in the summer of 1862. With the sudden appearance of Union military forces in the vicinity, Unionist Cherokees, including Ross, could finally show their true loyalty. As a result, the Confederate-Cherokee alliance lay in tatters.

The expedition also laid the groundwork for future offensives. Although most of the U.S. forces had retreated, the Indian Home Guard regiments maintained footholds in Cherokee Nation north of the Arkansas River. Furthermore, the expedition had managed to drive the Confederates southward. Most of Cherokee Nation had become a no-man's-land, where neither Confederates nor Federals retained dominance. This vacuum of power would make the Federal invasion of 1863 easier.

The vacuum of power created by the 1862 First Indian Expedition also created the space for banditry and guerrilla warfare. Although a second invasion in 1863 would bring a conventional military campaign back into Indian Territory, from 1862 to 1865 most the Territory remained a no-man's land where violence ruled. The result was tremendous civilian suffering and even more refugees, including Confederate Indians who sought refugees in north Texas. 
Stephen Foreman, who lived near Tahlequah in Cherokee Nation, recorded the constant fear and violence that suffocated the Nation in 1862. "There is a stir here, or a scheme at work in the dark that few can understand," Foreman confided to his diary. "I feel as if a heavy dark cloud hung over us." Foreman was a "Watie man," and often feared for his safety and that of his family from the hands of pro-Union Pin Indians. "My present calculation," Foreman declared on July 4, 1862, "is to remain at home if the Feds do come, and attend to my ordinary duties. If they take my life and destroy my property and houses, let all go together."106

The missionary wrote constantly about the latest rumors of killings and theft. In Foreman's eyes, the Pins ruled the countryside. "And all who do not belong to their party, and who have not fled to them for protection are robbed of everything...So to be a Watie man or an anti-pin is to be under sentence of death." One such Watie man was "Mr. Ursery, a white man with a Cherokee family;" the Pins "cut him up alive, it is said." At one point, Foreman heard rumors of his brother's death alongside another man. Although he doubted the veracity of the rumor of his brother's death, the other fellow—Abijah Hicks—was apparently truly dead. "He was an inoffensive man," Foreman wrote, "and if killed, it was either for his abolition sentiments or his property, for no one who has a good horse or any property is safe."107

On July 15, Stephen Foreman got a scare of his own. While sitting on his front porch with his children, he was visited by “two Pins piloted by one of Chief Ross' negroes.” Foreman thought they "looked as if they were hunting something." Ignoring Foreman's inquiries, the Indians ordered Foreman's slaves to return with them to Union camps. Foreman "could neither say nor do anything, knowing the whole place was surrounded by Pins." Not long after their

${ }^{106}$ Stephen Foreman, diary entries July 4, July 11, 1862, WHC, University of Oklahoma.

${ }^{107}$ Stephen Foreman, diary entries July 6, July 17 1862, WHC, University of Oklahoma; Confer, Cheroke Nation in the Civil War, 105. Emphasis in the original quote. It is unclear whether Alex Foreman was indeed killed. Abijah Hicks was indeed killed. Foreman reports it was at the hands of Watie men, Clarissa Confer's work indicates a mistaken Pin Indian killed Abijah. 
departure, one of Foreman's slaves - Charles_-"returned saying that he was sent after my horse," otherwise the Pin Indians would return. "It was hard to see my negroes taken off, and hard still to see my own negroes take off my horses," Foreman admitted. Still, Foreman let his slaves and horses go, for he thought the whole affair was a trick. By resisting the Pins' theft, he suspected "that would give them a pretext to come for them and kill me."108

That evening, one of his slaves returned to Foreman's home to warn him that the Unionists "were bound to kill me." At his children's pleas, Foreman spent the night in the cornfield, unwilling to hide any farther from home for fear that "if my children were killed and our houses and everything burnt up, I would be near and would go and suffer with them.” Fortunately, no soldiers appeared to kill Foreman. ${ }^{109}$

Later in the war, fifteen year old James Barnes witnessed a murder in cold blood by Confederate Choctaws. Visiting his uncle along the Arkansas-Territory border south of Fort Smith, Barnes' relatives were Unionists who spent their time "hiding in the timber and hills from the Rebels." One day, James was assigned to lookout for Confederates while the wanted men enjoyed a proper meal at the dining table. When James "saw a string of Rebels" approaching, he sounded the alarm and the men scampered. Everyone got away except for Jonathan Glenn, who was captured. Apparently unsatisfied with their haul, the Rebels continued down to the house of Flem Johnson. "Flem had the Pneumonia," James recalled, "and was expected by everyone to die. Rebels carried Flem out of his bed and set him against a tree and shot him to death." As if to compound the horrors James Barnes witnessed, a few days later after a local battle we

\footnotetext{
${ }^{108}$ Stephen Foreman, diary entry July 15, 1862, WHC, University of Oklahoma.

${ }^{109}$ Stephen Foreman, diary entry July 16, 1862, WHC, University of Oklahoma.
} 
watched a "Pin 'Indian' cut a patch of scalp about the size of the palm of their hand off the top of the dead Rebel's head.",110

Hannah Hicks — Abijah Hick's widow—struggled through the war as well. The death of her husband was far from her only misfortune. Her brother-in-law's home was burned, apparently for his pro-Confederate sentiments. She herself was robbed by Confederate soldiers in November, 1862, many of whom she recognized as men whom had dined at her table. She would endure four more robberies before the war ended. Hick's experience sheds light on how easily, and quickly, uniformed soldiers could turn into bandits, preying upon friend and foe alike. $^{111}$

Robberies and theft were common. Elizabeth Watts, a child during the war, remembered Southern soldiers robbing her home during the war. The Rebels took all of the Watts' food, including the green onions in the yard. They cut the feather bed to pieces, letting "the feathers fly in the wind." "They simply stripped us of everything. Mother took her best dress and sat on it to hide it. The made her get up and tore the dress into strings." Elizabeth and her family took refuge near Fort Gibson, where her father was a soldier and "we could draw on our rations like the soldiers." James Barnes and his family left the Territory in 1862 "on the account of Indian raids taking all the stock and grain, even the blankets out of the house." The family took shelter in Missouri, and James' father enlisted in the Union Army. ${ }^{112}$

Civil War Indian Territory fits nicely into the three-tiered world of Stephen Ash's When the Yankees Came. Ash argues that Federal invasions and subsequent occupations of Southern territory "created in effect not one occupied South but three: the garrisoned towns...the

\footnotetext{
${ }^{110}$ Interview with James Barnes, Indian Pioneer Papers, WHC, University of Oklahoma.

${ }^{111}$ Confer, Cherokee Nation in the Civil War, 105, 112.

112 Interview with Elizabeth Watts, Indian Pioneer Papers, WHC, University of Oklahoma; Interview with James Robert Barnes, Indian Pioneer Papers, WHC, University of Oklahoma.
} 
Confederate frontier... and no-man's land." Union outposts at Fort Gibson, Tahlequah and elsewhere provided some protection for Union refugees; likewise, the relative safety of Choctaw and Chickasaw Nations and Texas offered some security for Confederate refugees. Yet much of the borderlands - trapped between Union and Confederate zones of occupation — had also become a no-man's-land. Most of Cherokee, Creek, and Seminole Nations suffered from lawlessness, where instead banditry, thievery, and violence ruled. ${ }^{113}$

Guerrilla warfare, raids, and banditry were not unique to Indian Territory, but instead marred much of the Trans-Mississippi landscape. The violence in Indian Territory lends additional evidence to the historical scholarship of Michael Fellman, Daniel Sutherland, and Robert R. Mackey, all of whom document the rise and rule of guerrilla warfare that plagued Arkansas and Missouri from 1862 to 1865. Indeed, the retreat of the First Indian Expedition and the violent vacuum that ensued in the summer of 1862 coincides, as Daniel Sutherland has noted, with "the high point of public confidence in guerrilla war," which in turn "meant the end of conciliatory policies toward southern civilians on the border." In Arkansas, the failure of the Pea Ridge campaign in early 1862 encouraged Confederate commanders to rely upon guerrilla warfare. The resulting "Bands of Ten" order, which encouraged Southern patriots to form independent companies of at least ten men to harass the invading Federals, led to wanton banditry and destruction. In Arkansas, just as in Indian Territory, irregular forces and guerrillas initiated "wholesale looting of Unionists, immigrants, and later loyal Confederates [which] forced the population of Arkansas to flee to areas under military protection-Union or Confederate." Missouri was not exempt either; in fact, Michael Fellman declared the violence in Missouri "the worst guerilla war in American history." The violence and resulting refugees

${ }^{113}$ Stephen V. Ash, When the Yankees Came: Conflict and Chaos in the Occupied South, 1861-1865 (Chapel Hill: University of North Carolina Press, 1995): 77. 
blanketing Indian Territory were familiar scenes throughout the Trans-Mississippi region, and the violence helped harden Federal attitudes towards the South. ${ }^{114}$

The war's violence made most Indians refugees, and the numbers are simply astonishing. By 1863-'64, some 14,000 Indians were refugees in Confederate held lands. Records from March, 1865 indicate that some 17,100 Indian refugees were drawing rations from Union military authorities in Union held lands. Even with possible overlap in the figures, it is apparent that at least 30,000 Indians-60\% of Indian Territory’s 1860 population-left their homes and endured the hardships of refugee life during the war. This figure is even more astounding when one considers that the usual figure cited for Confederate refugees total is 200,000 . These refugees were forced to rely on others - be it Union authorities, other Indian tribes, or white neighbors - for sustenance. They suffered from disease, hunger, and lack of shelter. The Civil War in Indian Territory uprooted most of the population and left them destitute and far from home. ${ }^{115}$

The violence, suffering, and refugees that plagued Indian Territory throughout the Civil War were byproducts of the failure of either side to permanently occupy the landscape. Even with the appearance of Federal troops starting in 1862, most of Indian Territory lay outside the purview of regular Federal or Confederate protection. This vacuum of authority and order allowed banditry and violence to run unchecked, which in turn induced many Indians to leave their homes to try and survive in safer, occupied regions.

${ }^{114}$ Daniel E. Sutherland, A Savage Conflict: The Decisive Role of Guerillas in the American Civil War (Chapel Hill: University of North Carolina Press, 2009): 94-95; Robert R. Mackey, Uncivil War: Irregular Warfare in the Upper South, 1861-1865 (Norman: University of Oklahoma Press, 2004): 48-49; Michael Fellman, Inside War: The Guerilla Conflict in Missouri during the American Civil War (New York: Oxford University Press, 1989): xvi.

${ }^{115}$ LeRoy H. Fischer and William L. McMurry, "Confederate Refugees from Indian Territory," Chronicles of Oklahoma 57, no. 4 (1979): 451; Annie Heloise Abel, The American Indian and the End of the Confederacy, 1863-1866 (1925, Reprint. Lincoln: University of Nebraska Press, 1993): 68, n. 139; Susanna Michele Lee, "Refugees During the Civil War," May 23, 2012, Encyclopedia Virginia. 


\section{Conclusions}

The war in the Confederate borderland owed its existence not to questions of slavery or preservation of the Union, but instead to the mutually exclusive visions of sovereignty and future that traditionalist and acculturated Indians carried. When the United States broke asunder in the secession crisis of 1861 , it created a political and military vacuum that allowed acculturated Indians to bring their dream of Indian-Southern integration to fruition. For wealthy, elite individuals like Stand Watie and Robert Jones, who envisioned themselves as both Indians and Southerners, the prospect of a Confederate alliance glittered like gold. Receptive to the overtures of alliance promulgated by Indian agents and white neighbors, and fearful of missionary and Keetowah abolitionism, acculturated Indian elites led the Five Tribes to war on behalf of the Confederacy.

Yet many Indians — perhaps even a majority of Indians—did not share the elite's vision. Traditionalist Indians sought instead to preserve the sovereignty and culture of their tribes within the existing treaties of the United States. They often rejected the forms of acculturationplantation slavery, Christianity, contemporary dress, and more — that elite Indians affected, and they did not see Indian and Southern interests as intertwined. Alliance with the South, in traditionalist eyes, only offered war and devastation. The seemingly geopolitical impossibility of neutrality forced the Five-Tribes to choose sides, and all five tribal governments allied with the Confederacy. Yet traditionalist Indians found a way to voice their dissent. Gathering first under the leadership of Opothleyahola, then in turn enlisting in the Union blue of Indian Home Guard regiments, these Native-Americans sought to impose their own vision of sovereignty—one that placed primacy on an Indian, not Southern culture and future — on Indian Territory. 
The winter 1861 Confederate offensive against brought the first taste of violence to the Confederate borderland. White Southerners and acculturated Indians, brought together by mutual wartime interests, waged a war against both Unionist warriors and civilians in an effort to eliminate voices of anti-Confederate dissent in the Territory. The intent and brutality of the campaign adds complexity to historians understanding of the war generally; in a political backwater far from centers of power in Richmond and Washington D.C., the war took on harder dimensions far earlier than historians have acknowledged. The resulting campaign pushed Opothleyahola out of the country, but splintered the Cherokee-Confederate alliance and catalyzed Union plans for invading_or perhaps liberating-Indian homelands in the Territory.

The 1862 Union invasion of Indian Territory was the final blow to the ConfederateIndian unity. The projection of Federal power into the Territory offered thousands of Indians a real alternative to Confederate authority. Many Cherokees, including Chief John Ross, flocked to the Union standard, and it was apparent that John Ross' worst fears of intra-tribal warfare would come true. The Cherokees, Creeks, and Seminoles now rocked in the throes of intra-tribal civil war, and guerrillas and bandits ransacked the landscape. Scalping, murders, theft, and destruction - these were hallmarks of the war in the borderlands that appear from the very beginning. This brutality and violence adds even greater evidence to historians' depictions of guerrilla war in places like Arkansas and Missouri, suggesting that the Trans-Mississippi theater experienced a more savage Civil War generally than those places east of the Mississippi River.

The war raged on in Indian Territory for another three years. In 1863, the Federal Second Indian Expedition proved more successful than its predecessor, and at the Battle of Honey Springs in July the Union decisively defeated Confederate forces and ensured their dominance in the Territory. The subsequent two years brought an endless series of raids and skirmishes, and 
Indians on both sides served in campaigns outside the Territory's borders, but no more major campaigns in the Territory took place. Instead of battling the enemy, military authorities spent most of their time grappling with the growing numbers of destitute refugees. Although the war in Indian Territory began with a bang in 1861, it ended with a whimper in 1865 . Brigadier General Stand Watie - the only Native-American to achieve that rank during the Civil Warsurrendered his force on June 23, 1865, the last Confederate general to do so. ${ }^{116}$

It would be hard to underestimate the devastation reaped upon the Five Tribes during the American Civil War. Although the figures will never be exact, it is estimated that one-third of the Cherokee Nation, some 7,000 individuals, died during the Civil War. The Creeks lost nearly a quarter of their population, roughly 2,500 individuals, during the conflict. The Choctaw, Chickasaw, and Seminole Nations, which lay outside the Territory's main warzone, escaped similar death tolls, although undoubtedly many of members of these tribes died as well. These numbers eclipse the casualty rates for either the North or the South; the deadliest war in American history was even more lethal for Native Americans in their homeland.

Of course, surviving the conflict hardly meant life could return to the antebellum status quo. Two-thirds of the Five Tribes, some 30,000 souls, were refugees by war's end, and most did not know if they had a home to return to in 1865 . Families would never be the same; one in four Cherokee children, for example, were orphans by war's end. These numbers speak to the intensity of the war on the Confederate borderland, and they speak to the immense suffering of a people who were caught in a conflict not of their own making and in which many did not wish to fight. ${ }^{117}$

\footnotetext{
${ }^{116}$ Frank Cunningham, General Stand Watie's Confederate Indians, 197-198.

${ }^{117}$ Confer, Cherokee Nation in the Civil War, 145; Debo, The Road to Disappearance, 176; LeRoy H.
} Fischer and William L. McMurry, "Confederate Refugees from Indian Territory," Chronicles of Oklahoma 57, no. 4 (1979): 451; Annie Heloise Abel, The American Indian and the End of the Confederacy, 1863-1866 (1925, Reprint. 
The war in the borderland suggests that there is still much to uncover about seemingly well-worn topics within Civil War history. Despite its status as a near forgotten backwater, the Civil War saga of Indian Territory sheds light on some of the Civil War's greatest questions. In the Confederate borderland, Indian debates over sovereignty and the future led to one of the most violent, destructive, and forgotten chapters of the Civil War. Perhaps most importantly, however, the story of Civil War Indian Territory deserves to be told simply because, for those who lived it, this was the civil war. It was not epic, grand, or perhaps even militarily or politically consequential. Yet from a human perspective, it merits our attention. The horrific violence, destruction, and fear that stalked members of the Five Tribes and those who fought in the Confederate borderland deserve our acknowledgement and remembrance.

Lincoln: University of Nebraska Press, 1993): 68, n. 139; Carolyn Ross Johnston, Cherokee Women in Crisis: Trial of Tears, Civil War, and Allotment, 1838-1907, Contemporary American Indian Studies Series (Tuscaloosa: University of Alabama Press, 2003): 104. 


\section{Bibliography}

\section{Primary Sources}

Manuscripts \& Archival Materials

Oklahoma Historical Society, Oklahoma City, OK

George Fine Papers.

Opothleyahola File.

Presbyterian Historical Society, Philadelphia, PA

American Indian Correspondence

Western History Collection, University of Oklahoma, Norman, OK

Indian Pioneer Papers (Digitized).

Peter Pitchlynn Papers.

Stephen Foreman Papers.

Newspapers \& Magazines

Cherokee Advocate

Choctaw Intelligencer

Dallas Herald

The Standard [Clarksville, TX]

Printed Primary Sources

Bates, James C. A Texas Cavalry Officer's Civil War: The Diary and Letters of James C. Bates, edited by Richard Lowe. Baton Rouge: Louisiana State University Press, 1999.

Cater, Douglas John. As It Was: Reminiscences of a Soldier of the Third Texas Cavalry and the Nineteenth Louisiana Infantry, edited by T. Michael Parrish. Austin, TX: State House Press, 1990. 
Clarke, Isaac A. The Letters and Diaries of Isaac A. Clarke: Innovative Educator in Post-Civil War Arkansas, edited by Wayne Clark. Victoria, British Columbia: Trafford Publishing, 2006.

Dale, Edward Everett and Gaston Litton, eds. Cherokee Cavaliers: Forty Years of Cherokee History as Told in the Correspondence of the Ridge-Watie-Boudinot Family. 1939. Reprint, Norman: University of Oklahoma Press, 1995.

Grayson, George Washington. A Creek Warrior for the Confederacy: An Autobiography of Chief G.W. Grayson, edited by David Baird. Norman: University of Oklahoma Press, 1988.

Griscom, George L. Fighting with Ross' Texas Cavalry Brigade, C.S.A., edited by Homer L. Kerr. Hillsboro, TX: Hillsboro Junior College Press, 1976.

Report of the Commissioner of Indian Affairs. Washington, D.C. 1858-1860.

Ross, John. Papers of Chief John Ross, edited by Gary E. Moulton. 2 Vols. Norman: University of Oklahoma Press, 1985.

Smith, William R, “The Report of Hon. David Hubbard, Commissioner to Arkansas,” The History and Debates of the Convention of the People of Alabama. Atlanta: Wood, Hanleiter, Rice \& Co., 1861.

Sparks, A.W. The War Between the States, As I Saw It: Reminiscent, Historical and Personal. Tyler, Lee \& Burnett, Printers, 1901.

War of the Rebellion: A Compilation of the Official Records of the Union and Confederate Armies. 128 Vols. Washington, D.C., 1880-1902. 


\section{Primary Sources via Online Databases}

Ancestry Online Database, Ancestry.com

1850 United States Census

1860 United States Census

1860 United States Census-Slave Schedules

$\underline{\text { Fold3 Database, Fold3.com }}$

Compiled Service Records of Confederate Soldiers

\section{Secondary Sources}

Abel, Annie Heloise. The American Indian as Slaveholder and Secessionist. 1915. Reprint, Lincoln: University of Nebraska, 1992.

Adair County Court, State of Oklahoma. "Testimony of Sam Gilbreath,” February 21, 1916.

Ash, Stephen V. When the Yankees Came: Conflict \& Chaos in the Occupied South, 1861-1865.

Chapel Hill: University of North Carolina Press, 1995.

Bailey, Anne. "Douglas Hancock Cooper," The Confederate General. 2 Vols. William C.

Davis and Julie Hoffman, eds. National Historical Society, 1991.

Baird, W. David. Peter Pitchlynn: Chief of the Choctaws. Norman: University of Oklahoma Press, 1972.

Bates, Ed. F. History and Reminiscences of Denton County. Denton, TX: McNitzky Printing Company, 1918.

Bearss, Edwin C. "The Civil War Comes to Indian Territory, 1861: The Flight of Opothleyahola," Journal of the West 11 (Spring, 1972): 9-42.

Boyd, Joel D. “Creek Indian Agents, 1834-1874,” Chronicles of Oklahoma 51, no. 1 (1973): $37-58$. 
Broemeling, Carol B. “Cherokee Indian Agents, 1830-1874,” Chronicles of Oklahoma 50, no. 4 (1972): 437-473.

Brown, Thomas Elton. “Seminole Indian Agents, 1842-1874,” Chronicles of Oklahoma 51, no. 1 (1973): 59-83.

Bruce, Michael L. “'Our Best Men are Fast Leaving Us:' The Life and Times of Robert M. Jones," Chronicles of Oklahoma 66, no. 3 (1988): 294-305.

Bushong, Millard Kessler and Dean McKoin. Fightin’ Tom Rosser, C.S.A. Shippensburg, PA: Beidal Printing House, 1983.

Coleman, Louis. "Cyrus Byington: Missionary to the Choctaws," Chronicles of Oklahoma 62, no. 4 (1984): 360-387.

Confer, Clarissa. The Cherokee Nation in the Civil War. Norman: University of Oklahoma Press, 2007.

Crabb, Martha L. All Afire to Fight: The Untold Tale of the Civil War's Ninth Texas Cavalry. New York: First Post Road Press, 2000.

Debo, Angie. The Rise and Fall of the Choctaw Republic. $2^{\text {nd }}$ ed. Norman: University of Oklahoma Press, 1961.

------. The Road to Disappearance: A History of the Creek Indians. Norman: University of Oklahoma Press, 1941.

Doran, Michael F. "Negro Slaves of the Five Civilized Tribes," Annals of the Association of American Geographers 68, no. 3 (Sept., 1978): 335-350.

------. "Population Statistic of Nineteenth Century Indian Territory," Chronicles of Oklahoma 53, no. 4 (1975): 492-516. 
Fellman, Michael. Inside War: The Guerilla Conflict in Missouri during the American Civil War. New York: Oxford University Press, 1989.

Franks, Kenny A. Stand Watie and the Agony of the Cherokee Nation. Memphis: Memphis State University Press, 1979.

Freehling, William W. The South vs. The South: How Anti-Confederate Southerners Shaped the Course of the Civil War. New York: Oxford University Press, 2001.

Gibson, Arrell M. The Chickasaws. Norman: University of Oklahoma Press, 1971.

Hale, Douglas. The Third Texas Cavalry in the Civil War. Norman: University of Oklahoma Press, 1993.

Halliburton, Jr., R. Red Over Black: Black Slavery among the Cherokee Indians. Westport, CT: Greenwood Press, 1977.

Hamalainen, Pekka. The Comanche Empire. New Haven: Yale University Press, 2007.

Harris, William C. Lincoln and the Border States: Preserving the Union. Lawrence: University of Kansas Press, 2011.

Jewett, Clayton E. Texas in the Confederacy: An Experiment in Nation Building. Columbia: University of Missouri Press, 2002.

Krauthamer, Barbara. Black Slaves, Indian Masters: Slavery, Emancipation, and Citizenship in the Native American South. Chapel Hill: University of North Carolina Press, 2013.

Lee, Susanna Michele. "Refugees During the Civil War," May 23, 2012. Encyclopedia Virginia. Mackey, Robert R. The Uncivil War: Irregular Warfare in the Upper South, 1861-1865. Norman: University of Oklahoma Press, 2004.

McLoughlin, William G. After the Trail of Tears: The Cherokees' Struggle for Sovereignty, 1839-1880. Chapel Hill: University of North Carolina Press, 1993. 
------. Champions of the Cherokees: Evan and John B. Jones. Princeton: Princeton University Press, 1990.

------. The Cherokees and Christianity, 1794-1870: Essays on Acculturation and Cultural Persistence. Athens: University of Georgia Press, 1994.

Minges, Patrick N. Slavery in the Cherokee Nation: The Keetowah Society and the Defining of a People, 1855-1867. New York: Routledge, 2003.

Moulton, Gary Evan. “John Ross, Cherokee Chief.” PhD diss., Oklahoma State University, 1974.

Oates, Stephen B. Confederate Cavalry West of the River. 1961. Reprint, Austin: University of Texas Press, 1994.

Piston, William Garrett and Richard W. Hatcher III. Wilson's Creek: The Second Battle of the Civil War and the Men Who Fought It. Chapel Hill: University of North Carolina Press, 2000.

Sutherland, Daniel E. A Savage Conflict: The Decisive Role of Guerrillas in the American Civil War. Chapel Hill: University of North Carolina Press, 2009.

Thoburn, Joseph B. A Standard History of Oklahoma. 2 Vols. Chicago: American Historical Society, 1916.

White, Christine Schultz and Benton R. Now the Wolf Has Come: The Creek Nation in the Civil War. College Station: Texas A\&M University Press, 1996.

White, Richard. The Middle Ground: Indians, Empires, and Republics in the Great Lakes Region, 1650-1815. New York: Cambridge University Press, 1992. 
White, William A. “The Texas Slave Insurrection of 1860.” Southwestern Historical Quarterly 52, no. 3 (Jan., 1949): 259-285. ${ }^{118}$

Yarbrough, Fay A. Race and the Cherokee Nation: Sovereignty in the Nineteenth Century. Philadelphia: University of Pennsylvania Press, 2008. 